
February 1938

\title{
FIRE TESTS OF TREATED AND UNTREATED WOOD PARTITIONS
}

\author{
By Clement R. Brown
}

\section{ABSTRACT}

Fire-endurance tests were made of 13 wood partitions $4 \mathrm{ft}$ square and of four partitions $10 \mathrm{ft}$ high and $16 \mathrm{ft}$ wide. Some of the smaller partitions were of untreated longleaf pine, while the others were made of longleaf pine impregnated with various amounts of monoammonium phosphate up to 17 percent by weight. They were built either of one, two, or three plies of $3 / 4$-in. boards, or of a $13 / 4$-in. core with $3 / 16$-in. veneers, giving a total thickness of $21 / 8$ in. The large partitions were of the latter design and were made of treated birch. The results of the tests of the small panels are compared with results of fire-tube and flame-penetration tests made on specimens representative of each panel.

\section{CONTENTS}

I. Introduction

II. Fire-endurance tests $\ldots \ldots \ldots \ldots$

1. Material and treatment

2. Construction

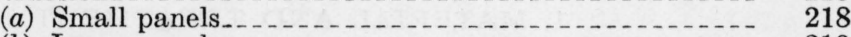

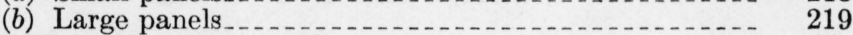

3. Fire tests and results



(b) Method of testing .

(c) Observations and results....... 223

1. Small panels

2. Large panels

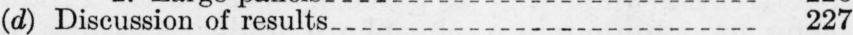

III. Supplementary tests and results_._.

1. Specimens.

2. Fire-tube tests

3. Flame-penetration tests

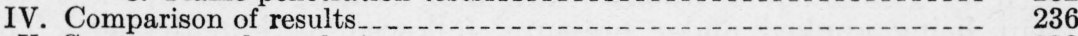

V. Summary and conclusions....... 238

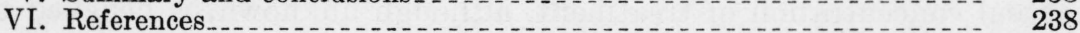

\section{INTRODUCTION}

Recent interest in the use of fire-retardant treated wood has revived the demand for reliable methods of classifying such material both in terms of its resistance to fire and its fire hazard compared to that of untreated wood. As a result, several testing methods have been studied during the past few years by the Forest Products Laboratory, U. S. Department of Agriculture [1] ${ }^{1}$; by Hartman, Williams, and

\footnotetext{
${ }^{1}$ Numbers in parentheses indicate the references at the end of this paper.
} 
Bastress [2]; and by the National Bureau of Standards. That part of the Bureau's investigation dealing principally with the extent to which the fire-tube and flame-penetration tests indicate the tendency of wood to spread fire, has been reported in a paper published in 1935 [3].

The fire resistance of structural elements is usually determined by tests of relatively large specimens according to procedures similar to that described in ASA Standard A2-1934 [4], which formed the basis of the present tests. These tests indicate the performance, under specified test conditions, of a given type of construction in terms of ability to sustain a load when exposed to fire, to prevent the occurrence of unduly high temperatures on the unexposed side, and to retard the passage of flame or hot gases through the construction. Although this and similar testing procedures have been occasionally applied to floors, partitions, and doors constructed of treated wood [5], the tests usually have not been carried to failure of the structure, nor have they permitted direct comparisons between treated and untreated wood.

The present paper gives the results of fire-endurance tests on thirteen 4-ft-square partitions built of longleaf pine and varying in thickness, design, and concentration of treatment, and of four 10- by $16-\mathrm{ft}$ treated birch partitions. In addition, fire-tube and flame-penetration tests were made on specimens from the same lots of material, carefully selected and prepared so as to be representative of the particular panels. The results of these three types of tests have been compared to determine the value and limitations of each test for indicating the fire-retarding properties of treated wood.

\section{FIRE-ENDURANCE TESTS}

\section{MATERIAL AND TREATMENT}

All of the small partitions, except Nos. 6 and 7 (table 1), were constructed of longleaf pine obtained from the Forest Products Laboratory of the Department of Agriculture. Panels 6 and 7 were built of untreated shortleaf and longleaf pine from our own stock. The treated wood was prepared by the Forest Products Laboratory, using monoammonium phosphate under pressure, with kiln drying after treatment.

The four large partitions were constructed of fire-retardant treated birch by a commercial woodworking and treating concern, the treatment being applied under pressure, followed by kiln drying. The actual concentration of treatment, although unknown, is believed to be relatively high.

\section{CONSTRUCTION}

(a) SMALL PANELS

The small fire-test panels were all approximately $4 \mathrm{ft}$ square. Panels 1 to 10 , inclusive, were constructed in our own shop, using $7 / 8$-in. boards, 60 in. long, and from $2 \frac{1}{2}$ to 6 in. wide. The amount of treatment being known for each board, they were carefully selected and distributed in each panel so as to obtain about the same average amount of treatment throughout the panel. As noted in table 1, all of the boards in the first 10 panels were vertical, except the core boards of panel 3. The boards were planed to $3 / 4$ in. thickness, jointed, 
and grooved. The $1 / 4-$ by $1 / 2$-in. splines fitted tightly in to the grooves and no glue was used in the joints or between the plies. The plies were fastened together with several rows of nails on each side, and batten strips were nailed across the side unexposed to fire.

Figure 1 indicates the construction of panels 2 and 3 . Chromelalumel thermocouples (23 and 26 gage) were placed between the plies of the two- and three-ply panels, one couple in each of two opposite corners 12 in. from the adjacent sides, and one at the center of each panel, as shown in figure 1 .

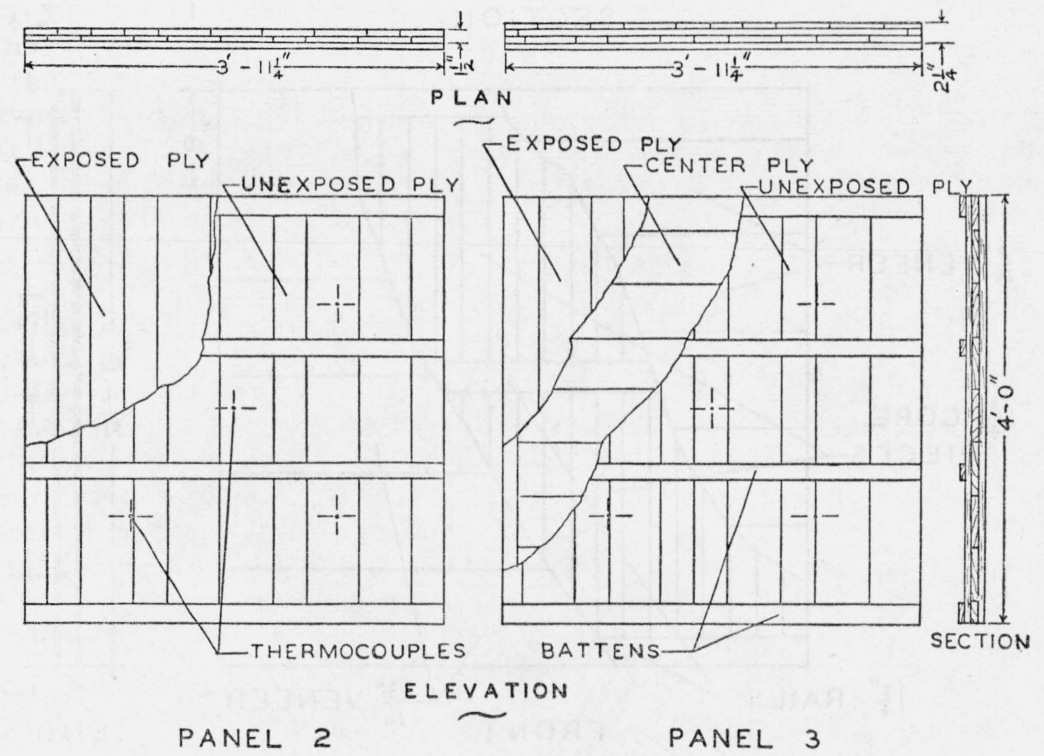

FIGURE 1.-Construction of panels 2 and 3 .

Panels 11, 12, and 13 were constructed, as shown in figure 2, by a commercial woodworking concern according to our specifications, from the same lots of material used in panels 8, 9, and 10. All joints were glued, the veneer pieces being glued to the core under pressure. No thermocouples were placed in the interior of these three panels.

\section{(b) LARGE PANELS}

The large panels were built by a commercial concern from wood treated in its own plant. The panels were $10 \mathrm{ft}$ high and $16 \mathrm{ft}$ long and were constructed in sections, each from $2 \mathrm{ft} 6$ in. to $3 \mathrm{ft} 2 \mathrm{in}$. wide. They were tongued and grooved on the edges so as to form smoke-tight joints when erected for the fire test. Figure 3 shows the construction of a section of panel $A$, which is typical for the large panels. The crossbanding of these panels corresponds structurally to the veneers in panels 11,12 , and 13 . All joints in the core were tongued and grooved and were glued together under pressure. The crossbands were about 6 or 7 in. wide and were glued to the core under pressure. The thicknesses of core and crossbanding used in the different panels were varied slightly in order to obtain the desired variation in total thickness of the panel. Table 1 also gives density 
data for two of the large panels but the moisture content at time of test was not definitely known for any of these panels.

Panels $A, B$, and $C$ were very similar in construction, but in panel $D$, a flush-type door was substituted for one of the sections. This door, $2 \frac{1}{8}$ in. thick, was similar in construction to the rest of the panel

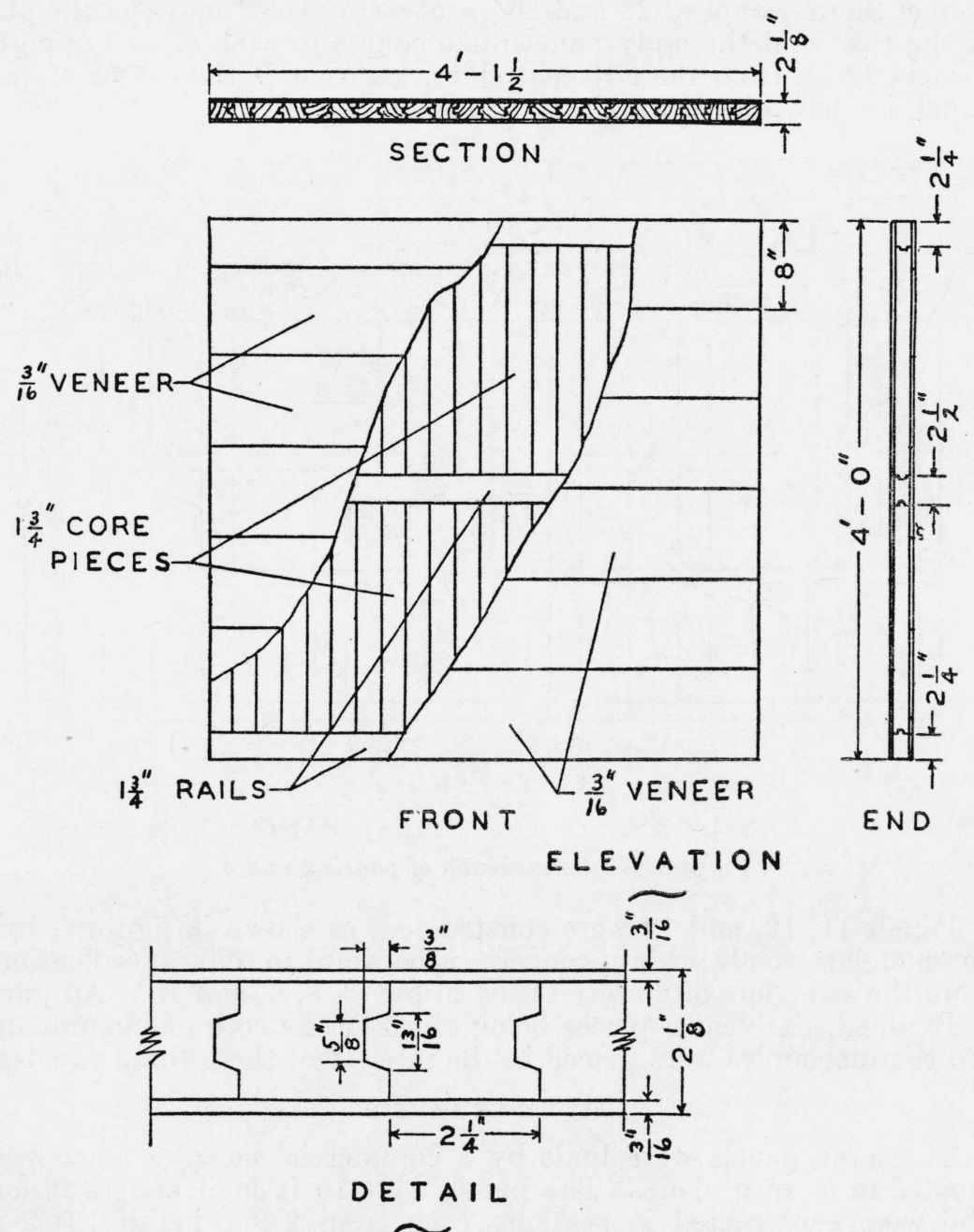

Figure 2.-Construction of panels 11, 12, and 18.

and hung to open toward the side to be exposed to fire. The edges of the door were beveled and the beveled door jambs were tongued on the back so as to fit into corresponding grooves in the adjacent panel sections. The clearance around the door on the exposed side varied from 0 to 0.05 in. and between door and stop on the unexposed side, from 0 to $0.09 \mathrm{in}$. The door fittings were of bronze and the hinge pins projected on the side of the panel to be exposed to fire. 
TABLE 1.-Description of partitions and results of fire-endurance tests

\begin{tabular}{|c|c|c|c|c|c|c|c|c|c|c|}
\hline \multirow{2}{*}{$\begin{array}{c}\text { Panel } \\
\text { number }\end{array}$} & \multirow{2}{*}{ Description } & \multirow{2}{*}{$\begin{array}{l}\text { Total } \\
\text { thick- } \\
\text { ness }\end{array}$} & \multirow{2}{*}{$\begin{array}{c}\text { Moisture } \\
\text { content } \\
\text { when } \\
\text { tested }\end{array}$} & \multirow{2}{*}{ Apparent } & \multicolumn{2}{|c|}{$\begin{array}{l}\text { Concentration of } \\
\text { treatment }{ }^{1}\end{array}$} & \multirow{2}{*}{$\begin{array}{l}\text { Light seen } \\
\text { through } \\
\text { panel }\end{array}$} & \multirow{2}{*}{$\begin{array}{c}\text { Flame } \\
\text { through } \\
\text { panel }\end{array}$} & \multirow{2}{*}{$\begin{array}{l}\text { Limiting } \\
\text { temper- } \\
\text { ature } \\
\text { reached }\end{array}$} & \multirow{2}{*}{ Failure by- } \\
\hline & & & & & Range & Average & & & & \\
\hline
\end{tabular}

(A) SMALL PANELS, PINE

\begin{tabular}{|c|c|c|c|c|c|c|c|c|c|c|}
\hline $\begin{array}{l}1 \\
2 \\
3 \\
4 \\
5 \\
6 \\
7 \\
9 \\
10 \\
11\end{array}$ & 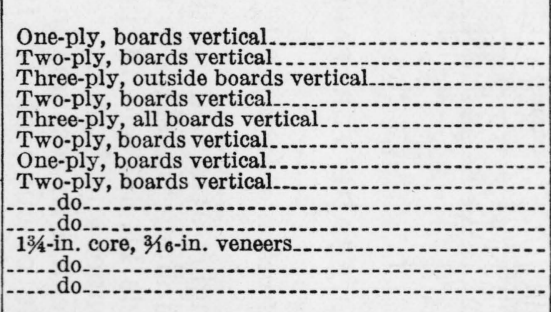 & $\begin{array}{r}\text { In. } \\
3 / 4 \\
11 / 2 \\
21 / 4 \\
112 \\
21 / 4 \\
112 \\
3 / 4 \\
11 / 2 \\
11 / 2 \\
112 \\
21 / 8 \\
218 \\
218\end{array}$ & $\begin{array}{r}\text { Percent } \\
8.8 \\
9.1 \\
8.6 \\
8.3 \\
9.7 \\
9.4 \\
8.1 \\
7.8 \\
8.8 \\
10.2 \\
8.4 \\
8.4 \\
11.4\end{array}$ & $\begin{array}{r}g / c m^{3} \\
0.64 \\
.63 \\
.61 \\
.65 \\
.62 \\
.61 \\
.61 \\
.57 \\
.58 \\
.57 \\
.57 \\
.58 \\
.60\end{array}$ & $\begin{array}{r}\text { Percent } \\
8.1 \text { to } 8.3 \\
7.6 \text { to } 8.9 \\
7.6 \text { to } 9.0 \\
6.6 \text { to } 7.3 \\
24.1 \text { to } 11.0 \\
\text { None } \\
\text { None } \\
\text { 13.6 to } 18.9 \\
13.4 \text { to } 19.2 \\
\text { None } \\
\text { 13.3 to } 22.2 \\
13.2 \text { to } 23.2 \\
\text { None }\end{array}$ & $\begin{array}{r}\text { Percent } \\
8.2 \\
8.2 \\
8.3 \\
6.9 \\
8.6 \\
\text { None } \\
\text { None } \\
15.9 \\
15.9 \\
\text { None } \\
17.0 \\
17.2 \\
\text { None }\end{array}$ & \begin{tabular}{r|} 
Min. \\
7.2 \\
27.4 \\
37.8 \\
29.0 \\
42.2 \\
28.5 \\
8.3 \\
30.0 \\
31.5 \\
30.0 \\
59.2 \\
68.4 \\
63.3
\end{tabular} & $\begin{array}{r}\text { Min. } \\
9.4 \\
29.5 \\
40.5 \\
31.1 \\
45.3 \\
29.4 \\
8.9 \\
34.5 \\
34.5 \\
32.7 \\
62.9 \\
72.1 \\
69.2\end{array}$ & \begin{tabular}{r} 
Min. \\
11.0 \\
28.3 \\
41 \\
30.5 \\
45.4 \\
\hdashline 31.5 \\
36.3 \\
32.3 \\
63.6 \\
67.0
\end{tabular} & $\begin{array}{l}\text { Flame. } \\
\text { Temperature. } \\
\text { Flame. } \\
\text { Temperature. } \\
\text { Flame. } \\
\text { Do. } \\
\text { Do. } \\
\text { Temperature. } \\
\text { Flame. } \\
\text { Temperature. } \\
\text { Flame. } \\
\text { Do. } \\
\text { Temperature. }\end{array}$ \\
\hline
\end{tabular}

(B) LARGE PANELS, BIRCH

\begin{tabular}{|c|c|c|c|c|c|c|c|c|c|}
\hline$A$ & 113/6-in. core, 1/8-in. veneers & $21 / 16$ & & & Unknown, but believed & 62 & 62 & 63 & Glow.3 \\
\hline B & $\begin{array}{l}\text { 13/4-in. core, 7/32-in. veneers... } \\
13 / 4 \text {-in. core, 3/6-in. veneers. }\end{array}$ & $\begin{array}{l}23 / 16 \\
216 \\
21 \% 8\end{array}$ & 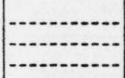 & $\begin{array}{r}0.79 \\
.77\end{array}$ & $\mid$\begin{tabular}{ll}
-1 \\
\hdashline do
\end{tabular} & 61 & $\begin{array}{l}64.5 \\
61.5\end{array}$ & $\mid$ & $\begin{array}{l}\text { Flame. } \\
\text { Do. } \\
\text { None. }\end{array}$ \\
\hline
\end{tabular}

1 Ratio of dry salt to air-dry wood, by weight.

2 Only a few pieces of material with this low concentration, the rest being above 7.3 percent.
3 Glow on surface. 


\section{FIRE TESTS AND RESULTS}

(a) MOUNTING OF PANELS

The small panels were mounted in a 50-in.-square concrete frame, which was placed in front of the Bureau's small gas-fired wall furnace [6], the spaces between the panel and frame being filled in with asbestos, fire clay, and narrow strips of treated wood, where necessary.

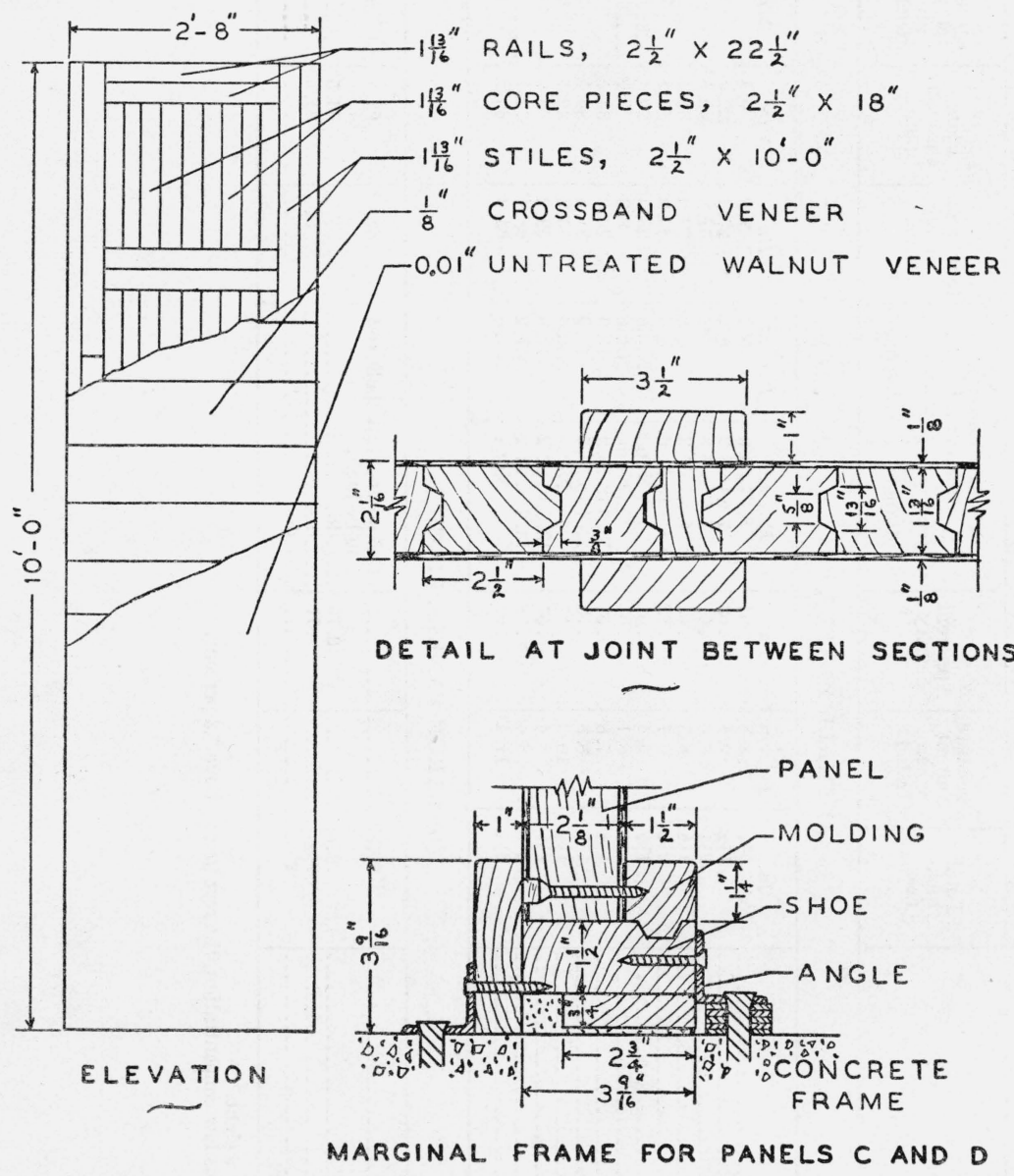

Figure 3.-Construction of large panels.

The panels were fastened to angles attached to the frame. Pieces of wood, $3 / 4$ by $13 / 4$ in., were nailed along the sides of the first 10 panels and all around the edges of panels 11,12, and 13, in order to make a reasonably tight joint between panel and frame.

The four large panels were erected in sections in a large steel and concrete frame having an inside opening of $10 \mathrm{ft} 1 \mathrm{in}$. by $16 \mathrm{ft}$. Panels $A$ and $B$ were held in place by means of 2 - by $2 \frac{1}{2}-$ in. marginal strips of treated birch, which were fastened to the concrete frame with angles and expansion bolts. The special marginal frame shown in figure 3 was used for panels $C$ and $D$. All openings between the 


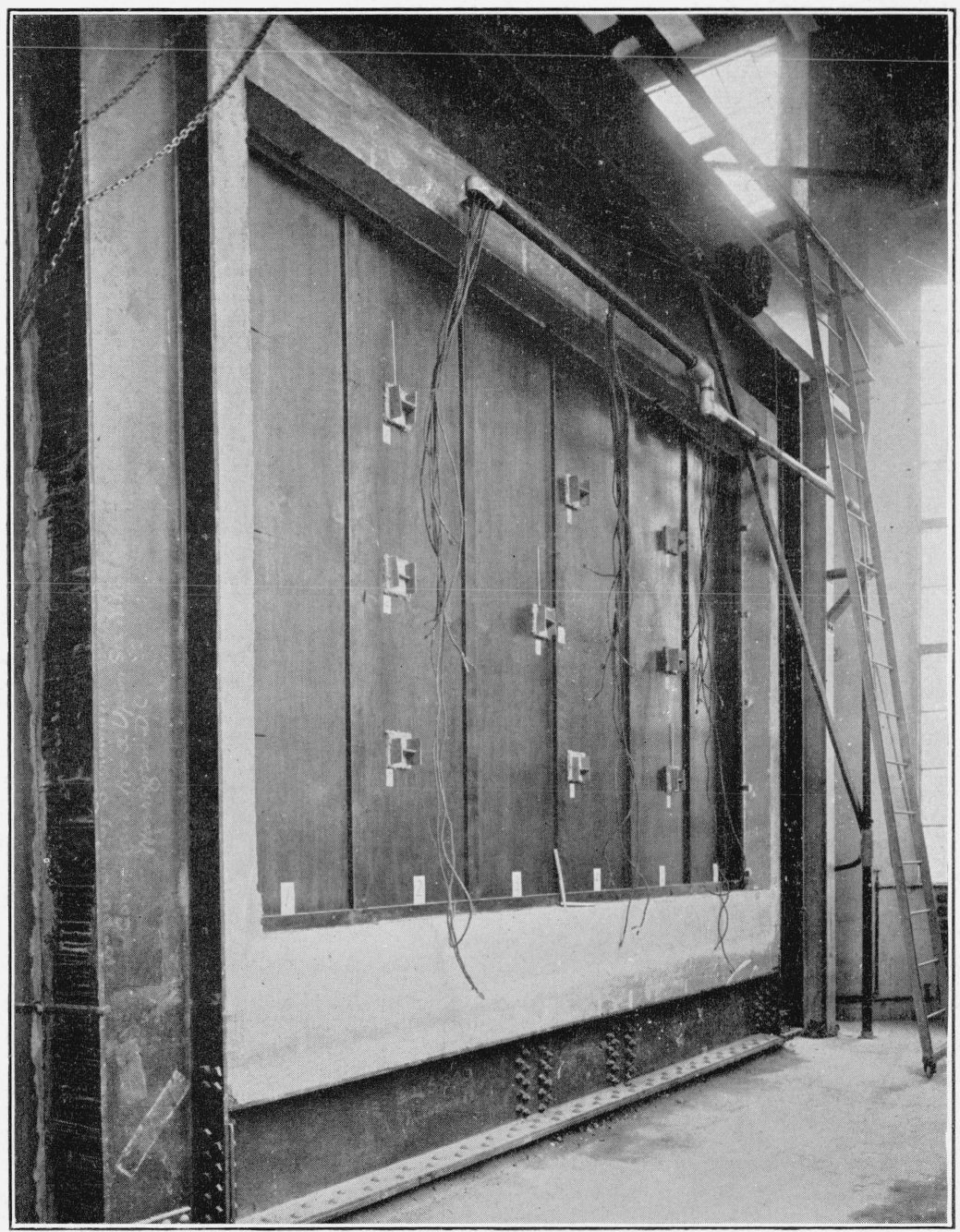

Figure 4.-Panel B mounted in furnace ready for test. 


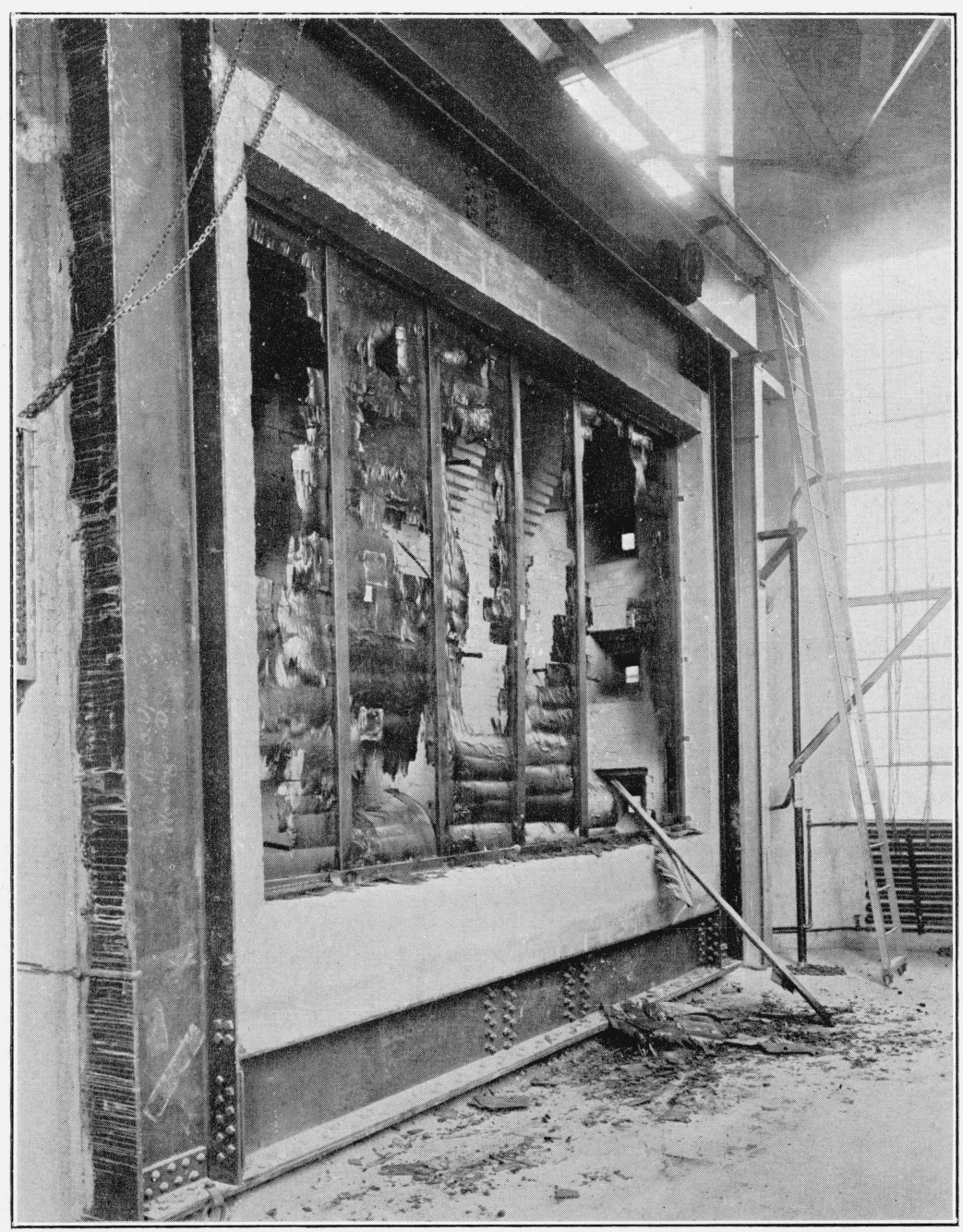

FiguRE 7.-Unexposed side of panel B after fire exposure. 
panel and the frame were filled with asbestos cement. The joints between the sections of all panels were covered with 1 - by $3 \frac{1}{2}$-in. batten strips, also of treated birch.

\section{(b) METHOD OF TESTING}

The tests were conducted in accordance with the specifications for fire tests of building construction and materials of the American Standards Association [4]. Temperatures in the furnace were measured with 18-gage chromel-alumel thermocouples, six being used in the small furnace and nine in the large furnace. Except for the test of panel $B$, the furnace exposure was controlled so as to give indicated furnace temperatures approaching as nearly as possible those given by the reference time-temperature curve. In the case of panel $B$, the average furnace temperature followed the reference curve for the first half hour and was then increased more rapidly in an attempt to obtain an average exposure of $1,700^{\circ} \mathrm{F}$ for the last half hour.

Temperatures on the unexposed surface of the small panels were measured with five fine-wire chromel-alumel thermocouples placed under 6 - in.-square felted-asbestos pads 0.4 in. thick. One couple was located at the center and one in each of the four corners, 12 in. from the edges of the panel. Thermometers were placed under three of the pads. As already mentioned, fine-wire thermocouples were placed between the plies of panels 2 to 6 and 8 to 10 , inclusive.

Nine fine-wire chromel-alumel thermocouples were placed under pads on the unexposed surface of the large panels, but no couples were placed between the plies. The surface thermocouples were located at or close to the intersection of the lines dividing the panel surface vertically and horizontally into quarters. Thermometers were placed under three of the pads on these panels also.

Deflection measurements relative to stationary vertical wires were taken on the large panels at points close to the thermocouple pads. Figure 4 shows panel $B$ in place in front of the furnace before test.

In conducting the test the criterion of failure was taken as any one of the following: An average temperature rise of $139^{\circ} \mathrm{C}\left(250^{\circ} \mathrm{F}\right)$ above the initial, as shown by the surface thermocouples; a maximum temperature rise of $181^{\circ} \mathrm{C}\left(325^{\circ} \mathrm{F}\right)$ above the initial at any one thermocouple location; or the appearance of flame on the unexposed surface. The test was discontinued shortly after any one of the above endpoints was reached.

All of the tests were fire-endurance tests except that on panel $D$, which was a fire test for $1 / 2 \mathrm{hr}$, immediately after which the panel was removed and a hose stream applied to the exposed surface for 2.4 minutes.

\section{(c) OBSERVATIONS AND RESULTS}

1. Small Panels.-The temperature records for 6 of the 17 fire tests are given in figures 5 and $6 . \quad F \max , F$ avg, and $F$ min denote the time-temperature curves for the furnace maximum, average, and minimum, respectively. The control of the furnace was based on the curve marked "Reference Curve." Maximum and average temperatures indicated by the surface thermocouples are denoted by $C$ max and $C$ avg, respectively, while $T$ denotes the surface tem$38682-38-9$ 
peratures, as indicated by the thermometers, and $R$ indicates the room temperature during test. For the two-ply panels, the curves marked 1 are the average temperatures indicated by the fine-wire

TEMPERATURE IN DEGREES FAHRENHEIT

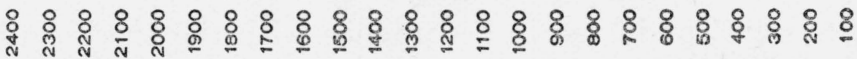
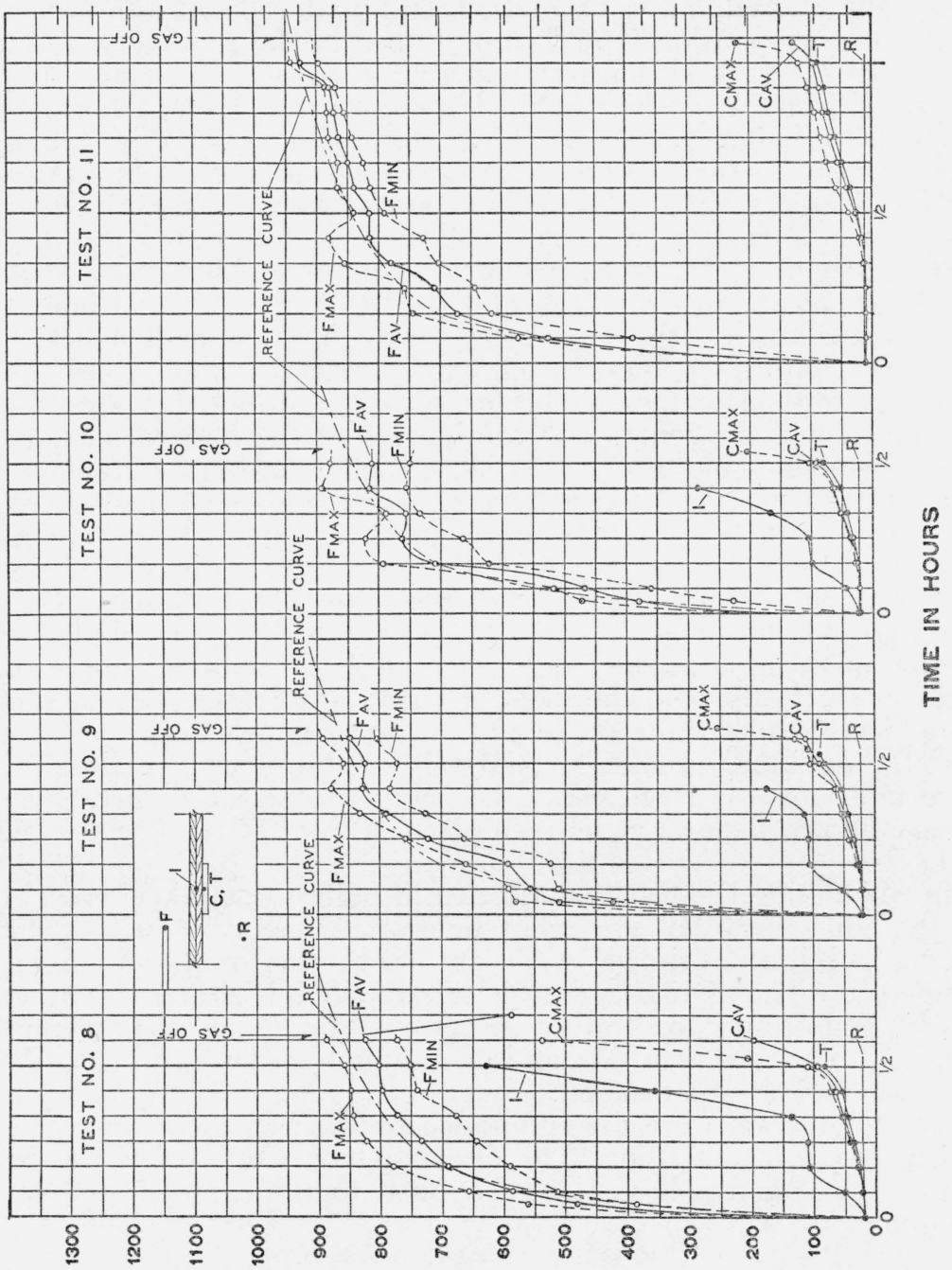

TEMPERATURE IN DEGREES CENTIGRADE

FigURe 5.-Temperature records for fire tests of panels 8, 9, 10, and 11 .

couples between the plies, while for the three-ply panels the curves marked 1 refer to the interior location nearest the exposed side, and those marked 2, the location closest to the unexposed side.

The principal results of the tests are given in table 1 . The behavior of panels 1 to 10 , inclusive, was very similar except for the amount and character of flaming. The exposed surface was charred and began 
checking within the first $2 \mathrm{~min}$, and the joints in the ply nearest the fire began opening at from 9 to $18 \mathrm{~min}$. Short pieces of the boards of this ply began falling off the panel at from 21 to $25 \mathrm{~min}$, and most

TEMPERATURE IN DEGREES FAHRENHEIT

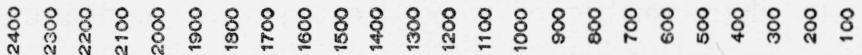

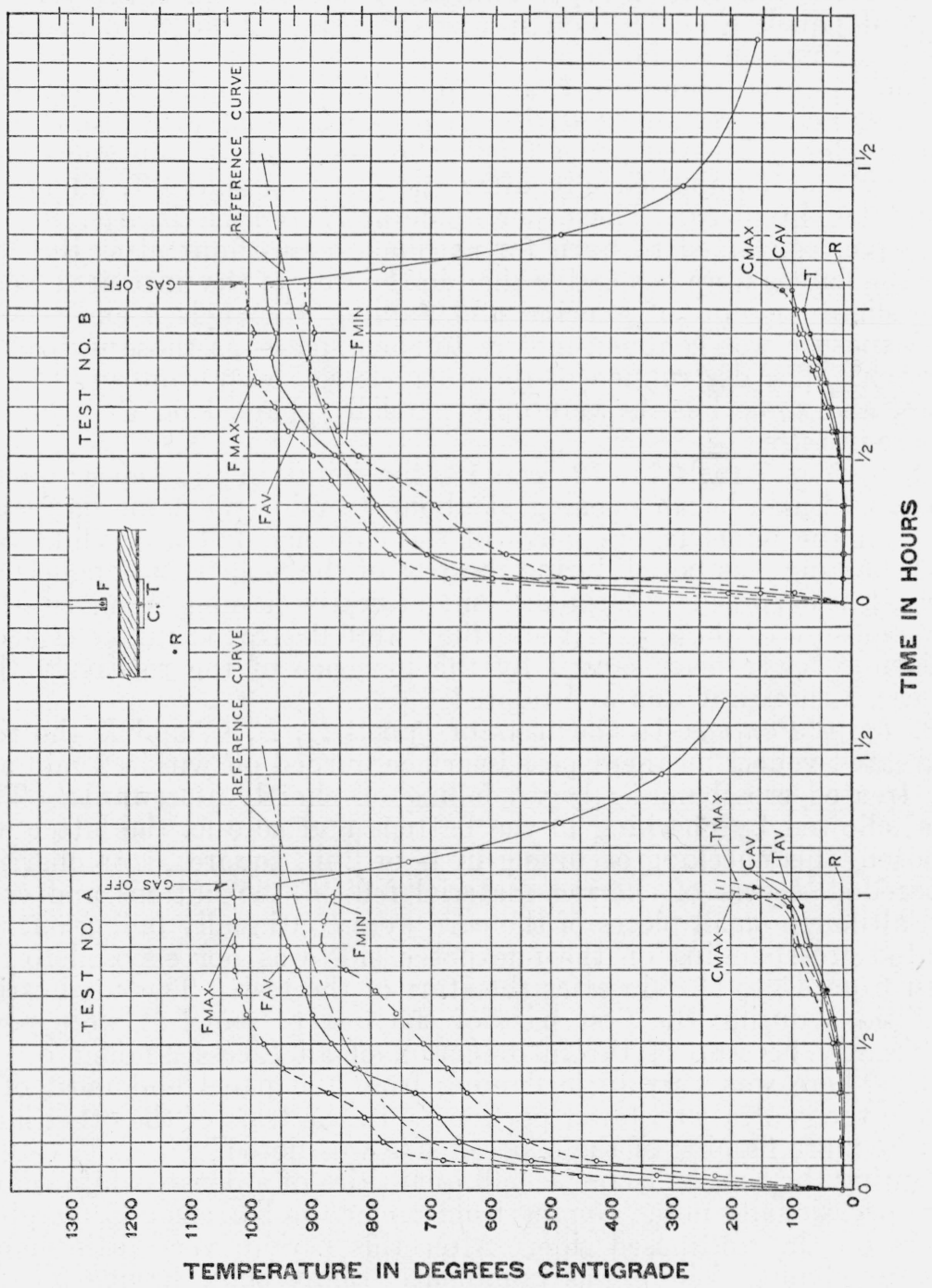

Figure 6.-Temperature records for fire tests of panels $A$ and $B$.

of this ply had fallen off within the next 5 or 6 min. This was followed by warping and opening of joints in the adjacent ply. In the case of the three-ply panels, 3 and 5 , the core boards began falling off at 34 and $36 \mathrm{~min}$, respectively. The time at which the joints in the unexposed ply had opened sufficiently to permit light from the furnace to be seen is given in table 1 . 
For the untreated panels, periods of vigorous, active flaming alternated with periods of subdued flaming during fire exposure. The flaming during the exposure of the moderately treated panels, 1 to 5, inclusive, was sometimes similar to that for the untreated panels, but less intense. At other times the flames were of the short, greenishblue variety characteristic of wood treated with monoammonium phosphate. The latter type of flames predominated entirely in the tests of panels 8 and 9 , and it was sometimes difficult to maintain good combustion in the furnace.

The untreated panels 6,7 , and 10 continued flaming actively after the test and were almost entirely consumed in about 15 min more. The single-ply treated panel 1 failed in less than $10 \mathrm{~min}$ and ceased glowing and flaming shortly after the gas was shut off, all boards remaining in place. The other moderately treated panels, 2 to 5, inclusive, continued to burn for as much as an hour after the test, but the flames were less active than in the case of the untreated wood. The slight amount of glowing and flaming of panels 8 and 9 after fire exposure was confined mostly to such spaces as those in back of battens. The destruction of these panels was very slow and incomplete, and some boards were only partially charred on the side not exposed to fire.

In tests of panels 11,12 , and 13 , the joints in the veneer on the unexposed side began opening at about $40 \mathrm{~min}$ and flame had come through the panel before much of the core had fallen. While very little flaming was noted during the test of the well-treated panels, 11 and 12, a surprisingly large amount of active flaming occurred after fire exposure of these panels and they were destroyed rather quickly. This may have been caused by the presence of the relatively thin veneer, although it was well treated.

2. Large Panels.- In the tests of panels $A, B, C$, and $D$ the thin untreated veneer on the exposed surface burned off within 2 min and the treated crossbanding began falling off shortly afterwards. This was followed by checking in the battens and core as the latter was exposed, this checking occurring in 1- or 2-in. squares. As charring proceeded, layers of charred material fell off the battens and core, and although small pieces of the core were continually falling off, the treated crossbanding on the unexposed side was not exposed to fire until from 47 to $63 \mathrm{~min}$ after the start of the test. The combustion conditions during the first part of the test of panel $A$ were poor; apparently because of the introduction of an excess amount of gas fuel. There was very little flaming from the panel and most of it was in the central and lower portions. In the tests of the other large panels, more flaming of the exposed side was noted.

During the first half-hour, small quantities of a dense, white smoke were occasionally noted coming from under the battens and marginal pieces on the unexposed side. After this period, very little smoke was noted until failure was imminent. Shiny spots having an oily appearance began to show on the unexposed surface after $35 \mathrm{~min}$. Warping of this surface and apparent buckling of the panel were first noted at about $45 \mathrm{~min}$. Failure by flame penetration was preceded by the appearance of a blister on the unexposed surface, which soon turned black and then cracked, glow or flame appearing a few minutes later. In the case of panel $A$, glow appeared on the surface at 62 min, and as a cotton pad in contact with the glowing surface was 
ignited, this time was taken as failure, although flame did not appear until several minutes later.

The deflection of the large panels was relatively small, varying from $3 / 8$ in. towards the fire to $3 / 8$ in. away from the fire for all the panels.

Intermittent flaming at various points on the unexposed surface continued for about 10 or 12 min after fire exposure of panels $A, B$, and $C$, although glow and short flames were noted in the interior and behind battens and marginal pieces for several hours. Disintegration of the core and crossbanding proceeded rapidly during this period, undoubtedly being aided by heat rising from burning debris in the furnace pit and also radiation from the back wall of the furnace. After cooling, approximately two-thirds of the unexposed surface of panel $A$, and about one-third of this surface of panels $B$ and $C$, were still in place. Figure 7 shows panel $B$ after the fire test.

During the "fire exposure of panel $D$, smoke was seen to be issuing: in small quantities from several points along the edges of the door within the first few minutes, and again at $12 \mathrm{~min}$, when the air pressure in the furnace was momentarily increased above normal. After 22 min, smoke began coming from the top edge of the door in regular puffs and increased in volume until the end of the test. mum clearance on this edge increased from $\frac{1}{4}$ in. at 19 min to nearly $1 / 2$ in. at $26 \mathrm{~min}$. Immediately after shutting off the gas, the panel was removed and the hose stream applied to the exposed side for $2.4 \mathrm{~min}$. Water came over the top of the door and ran down the unexposed side before the end of the hose-stream application, and the force of the stream caused some loose pieces of charred core and nearly all battens on the exposed side to fall off, but the stream did not penetrate the core. Figure 8 shows the exposed side of this panel after the fireendurance and hose-stream test.

When this panel was dismantled, it was found that the screws holding the door hinges were all loose, and the door was pulled out of place without much difficulty. Charring had extended to the unexposed side along a portion of the top edge of the door and also on the inside edge from the upper hinge to the top. The door jambs and stops were also charred to the greatest extent on those surfaces adjacent to hardware. For the most part, the depth of char in the central portions of the door, as well as each panel section, was less than half the thickness of the panel.

\section{(d) DISCUSSION OF RESULTS}

The principal quantitative result obtained in the fire-endurance test is the fire-endurance period, as measured by the time of failure. The small panels differed chiefly in thickness, amount of treatment, and type of construction. Figure 9 (upper half) shows the relation between the time of failure and thickness for panels 1, 2, and 5, which are comparable in construction and concentration of treatment. This relation is practically linear, differing in this respect from the behavior found for incombustible walls and partitions, the fire endurance of which increases approximately with the square of the thickness. From the lower half of figure 9 it is evident that concentration of treatment has very little (if any) effect on the time of failure in this particular type of test, at least in the range from 0 to 16 percent. Also, the untreated core and crossband panel 13 developed nearly the same fire endurance as the average for the heavily treated panels 11 
and 12 of similar construction. This may not necessarily hold for other species of wood or other treatments. On the other hand, the type of construction is an important factor. Table 1 shows that the performance of the core and crossband panels 11, 12, and 13 was much

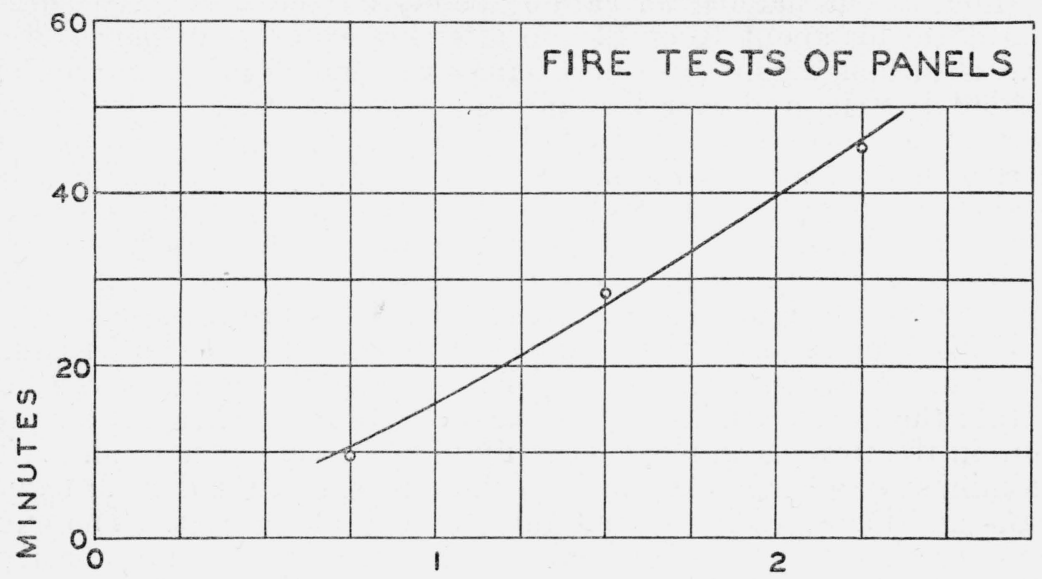

THICKNESS, INCHES

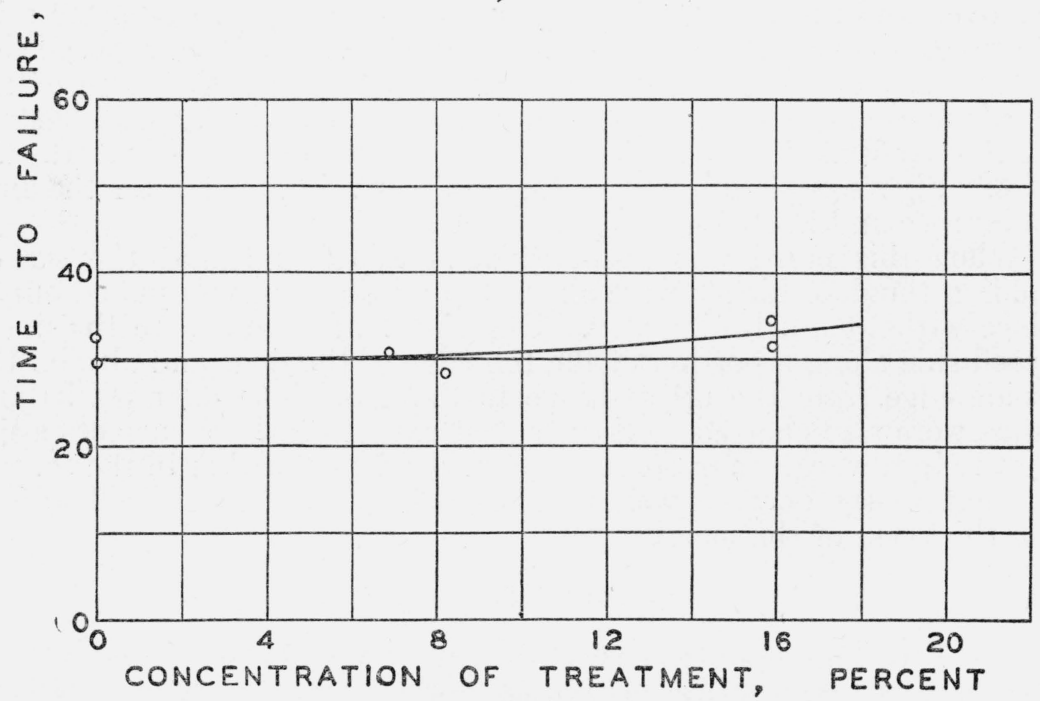

Figure 9.-Influence of thickness of panel and concentration of treatment on time of failure, in fire tests of partitions.

Data in upper half are from tests of panels 1,2, and 5. Data in lower half are from tests of panels 2, 4, 6, 8, 9, and 10 .

better than that of the ply panels 3 and 5, even though the latter had slightly greater thickness.

The large panels differed too little to permit a study of such factors as thickness and type of construction. They were similar in construction and thickness to small panels 11, 12, and 13, and although they differed from the latter in wood species and treatment details, there was very little difference between the results of the tests of these 


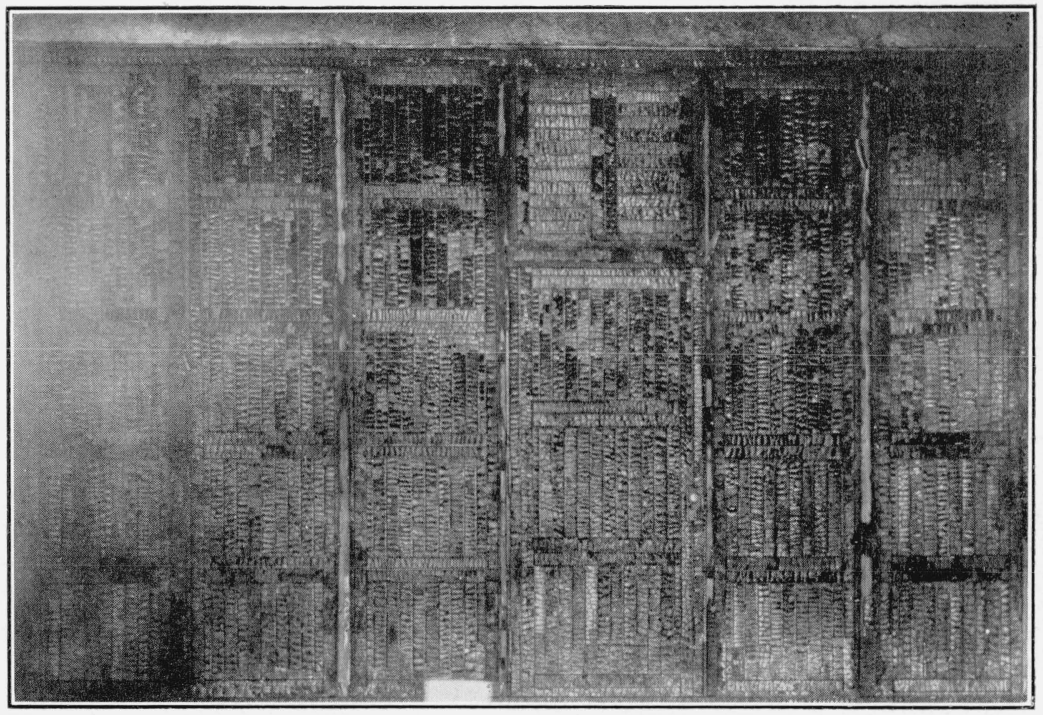

FiguRE 8.-Exposed side of panel D after fire exposure and hose-stream application. 


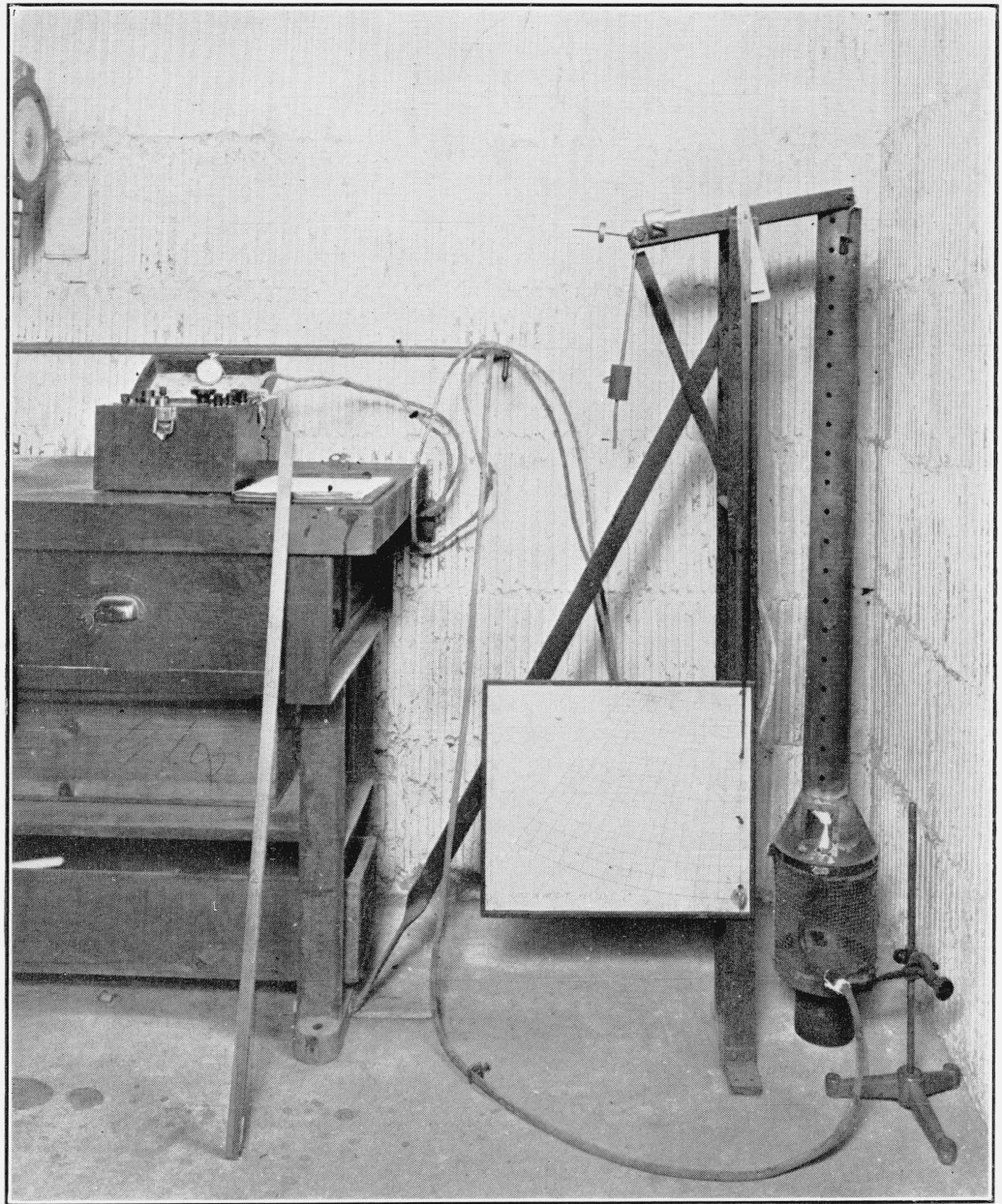

Figure 10.-Fire-tube apparatus. 
large and small panels. Considering also the relatively small deflections of the large panels, it appears that size of specimen in the range included does not greatly affect the fire endurance of wood partitions of the given type of construction. This point might be definitely decided by tests of panels of identical materials and construction.

The standard fire-test specification [4] states that assemblies which burn freely during fire exposure or continue flaming after the furnace is shut off shall be termed "combustible." Of the 13 small panels tested, the untreated and moderately treated panels can be said to have burned freely, at least at times, during fire exposure. "While some flaming was observed during the fire tests of panels $8,9,11$, and 12 , it was not the active flaming characteristic of untreated wood and therefore these might be classed as not "burning freely." The large partitions behaved similarly to the latter during fire exposure. All partitions, however, continued flaming after fire exposure, although in varying extent, depending upon concentration of treatment. In view of the latter fact, it appears that all of the 17 panels tested would be classed as "combustible" under the standard fire-test specification.

The standard fire-endurance test [4] used in the present work is based on the application of temperatures on one side of the partition which increase with time according to a prescribed schedule. In the case of a partition made up entirely of incombustible materials, all of the heat required to maintain these temperatures is necessarily supplied by the gas or other fuel used in the furnace. In the case of partitions built wholly or in part of combustible materials, however, some heat is supplied by the combustion of these materials. Consequently, in maintaining the same exposure temperatures, the amount of furnace fuel is reduced to compensate for this amount of heat supplied to the furnace by the burning of the partition itself. It is to be noted that, insofar as the latter forms a significant portion of the total exposure, the tests of partly or wholly combustible partitions differ from the tests of entirely incombustible partitions. Also under this test procedure the exposure given the combustible type of partition is less severe relative to that given the incombustible partition than it would be if the test required a definite amount of furnace fuel to be burned in a given time rather than the maintenance of a certain time-temperature relationship.

In the present tests, failure of both treated and untreated wood partitions was obtained in approximately equal periods of time, but probably with the supply of greater amounts of gas fuel in the tests of the treated wood partitions. Again, the amount of fuel used in a number of comparable tests of incombustible partition constructions was definitely greater than in the tests of treated wood partitions in the present series. In evaluating the performance to be expected from partitions such as these in an actual fire, the relative amounts of fuel supplied to maintain the same temperature rise within the furnace may be significant.

Whether or not these considerations are of importance in the present tests, attention is called to them as a precaution in the application of the results of fire-endurance tests of combustible or partly combustible partitions. In the design of buildings, the fire-resistance ratings of the different members are determined by the expected severity of fires that can occur in the given location. Hence, in 
estimating such fire severities, account should be taken of any combustible content of the partition selected as a barrier to fire, as well as the amount of combustibles within the building, such as furniture and other contents, and in other building members.

\section{SUPPLEMENTARY TESTS AND RESULTS}

\section{SPECIMENS}

For each of the small panels tested, three specimens for the flamepenetration test and five or six specimens for the fire-tube test were prepared from the material remaining after construction of the panel. Several fire-tube specimens representative of the treated birch used in the large panels were also obtained at the time of construction of the latter. The specimens for the flame-penetration test were about 10 in. square and of the same thickness and type of construction as the corresponding panel, being made from the ends of boards and splines cut off during the construction of the latter. The specimens for panels 11,12, and 13 were made at the plant where the panels were constructed.

In the case of the small panels, the fire-tube specimens were $3 / 8$ by $3 / 4$ in. and from 42 to 48 in. in length and were cut from unused boards, spline material, pieces ripped from end boards, rails, etc., of the material selected for the particular panel. For the large panels, some of the fire-tube specimens were selected at random by the manufacturer from his supply of treated birch and others were selected from boards to be used in the construction of certain parts of panel $D$.

TABLE 2.-Descriptive data for supplementary test specimens

\begin{tabular}{|c|c|c|c|c|c|c|c|c|c|c|c|c|c|}
\hline \multirow{3}{*}{$\begin{array}{c}\text { Panel } \\
\text { number }\end{array}$} & \multicolumn{6}{|c|}{ Fire-tube specimens } & \multicolumn{7}{|c|}{ Flame-penetration specimens } \\
\hline & \multirow{2}{*}{$\begin{array}{c}\text { Num- } \\
\text { ber }\end{array}$} & \multirow{2}{*}{$\begin{array}{l}\text { Mois- } \\
\text { ture as } \\
\text { tested }\end{array}$} & \multirow{2}{*}{$\begin{array}{l}\text { Appar- } \\
\text { ent } \\
\text { density }\end{array}$} & \multicolumn{3}{|c|}{$\begin{array}{l}\text { Concentration of } \\
\text { treatment }\end{array}$} & \multirow{2}{*}{$\begin{array}{c}\text { Num- } \\
\text { ber }\end{array}$} & \multirow{2}{*}{$\begin{array}{c}\text { Thick- } \\
\text { ness }\end{array}$} & \multirow{2}{*}{$\begin{array}{l}\text { Mois- } \\
\text { ture as } \\
\text { tested }\end{array}$} & \multirow{2}{*}{$\begin{array}{l}\text { Ap- } \\
\text { par- } \\
\text { ent } \\
\text { den- } \\
\text { sity }\end{array}$} & \multicolumn{3}{|c|}{$\begin{array}{l}\text { Concentration of } \\
\text { treatment }\end{array}$} \\
\hline & & & & $\begin{array}{l}\text { Min- } \\
\text { imum }\end{array}$ & $\begin{array}{l}\text { Max- } \\
\text { imum }\end{array}$ & $\begin{array}{c}\text { Aver- } \\
\text { age }\end{array}$ & & & & & $\begin{array}{l}\text { Min- } \\
\text { imum }\end{array}$ & $\begin{array}{l}\text { Max- } \\
\text { imum }\end{array}$ & $\begin{array}{l}\text { Aver- } \\
\text { age }\end{array}$ \\
\hline 5 & $\begin{array}{l}3 \\
6 \\
6 \\
6 \\
6\end{array}$ & $\begin{array}{r}\text { Percent } \\
6.6 \\
7.0 \\
6.1 \\
6.9 \\
9.9\end{array}$ & $\begin{array}{r}\mathrm{g} / \mathrm{cm}^{3} \\
0.63 \\
.56 \\
.58 \\
.62 \\
.61\end{array}$ & $\begin{array}{c}\text { Per- } \\
\text { cent } \\
-7.6 \\
7.6 \\
6.8 \\
4.1\end{array}$ & $\begin{array}{c}\text { Per- } \\
\text { cent }\end{array}$ & $\begin{array}{l}\text { Per- } \\
\text { cent } \\
8.2 \\
8.4 \\
8.0 \\
7.0 \\
8.4\end{array}$ & $\begin{array}{l}3 \\
3 \\
3 \\
3 \\
3\end{array}$ & $\begin{array}{l}\text { In. } \\
3 / 4 \\
11 / 2 \\
21 / 4 \\
11 / 2 \\
21 / 4\end{array}$ & \begin{tabular}{|c} 
Percent \\
8.8 \\
9.1 \\
8.6 \\
8.3 \\
9.7
\end{tabular} & $\begin{array}{c}\mathrm{g} / \mathrm{cm}^{3} \\
0.60 \\
.57 \\
.58 \\
.61 \\
.59\end{array}$ & $\begin{array}{c}\text { Per- } \\
\text { cent } \\
8.1 \\
7.6 \\
7.6 \\
6.6 \\
4.1\end{array}$ & $\begin{array}{r}\text { Per- } \\
\text { cent } \\
8.3 \\
8.9 \\
9.0 \\
7.3 \\
11.0\end{array}$ & \begin{tabular}{|l} 
Per- \\
cent \\
8.2 \\
8.2 \\
8.2 \\
7.0 \\
8.5
\end{tabular} \\
\hline $\begin{array}{l}9 \\
10 \\
0 . . .\end{array}$ & $\begin{array}{l}3 \\
3 \\
6 \\
6 \\
6\end{array}$ & $\begin{array}{l}8.6 \\
7.8 \\
7.4 \\
7.4 \\
8.6\end{array}$ & $\begin{array}{l}.60 \\
.60 \\
.69 \\
.68 \\
.62\end{array}$ & $\begin{array}{l}13.6 \\
14.5\end{array}$ & \begin{tabular}{|l|} 
\\
\hdashline 18.9 \\
18.3
\end{tabular} & $\begin{array}{c}0 \\
0 \\
15.8 \\
16.0 \\
0\end{array}$ & $\begin{array}{l}3 \\
3 \\
3 \\
3 \\
3\end{array}$ & $\begin{array}{r}11 / 2 \\
3 / 4 \\
11 / 2 \\
11 / 2 \\
11 / 2\end{array}$ & $\begin{array}{l}9.4 \\
8.1 \\
8.2 \\
8.4 \\
9.6\end{array}$ & $\begin{array}{l}.59 \\
.61 \\
.63 \\
.66 \\
.57\end{array}$ & $\begin{array}{l}-14.3 \\
14.1\end{array}$ & \begin{tabular}{l}
..- \\
\hdashline 17.6 \\
18.3
\end{tabular} & $\begin{array}{c}0 \\
0 \\
15.8 \\
16.2 \\
0\end{array}$ \\
\hline $\begin{array}{l}11 \ldots \\
12 \ldots \\
13 \ldots\end{array}$ & $\begin{array}{l}5 \\
5 \\
5\end{array}$ & $\begin{array}{r}9.3 \\
8.9 \\
10.3\end{array}$ & $\begin{array}{l}.62 \\
.64 \\
.66\end{array}$ & $\begin{array}{l}15.0 \\
14.9\end{array}$ & $\begin{array}{l}17.6 \\
15.6\end{array}$ & $\begin{array}{c}16.2 \\
15.2 \\
0\end{array}$ & $\begin{array}{l}3 \\
3 \\
3\end{array}$ & $\begin{array}{l}21 / 8 \\
21 / 8 \\
21 / 8\end{array}$ & $\begin{array}{r}8.7 \\
10.2 \\
11.4\end{array}$ & $\begin{array}{l}.64 \\
.66 \\
.58\end{array}$ & & & $\begin{array}{l}17.0 \\
17.2 \\
0\end{array}$ \\
\hline$C_{-}$ & $\begin{array}{l}3 \\
7\end{array}$ & 10.3 & $\begin{array}{l}.78 \\
.64\end{array}$ & & & & & $\begin{array}{r}\text { No spe } \\
\text { D } \\
\text { D } \\
\text { D }\end{array}$ & $\begin{array}{l}\text { cimens. } \\
0 . \\
0 . \\
0 .\end{array}$ & 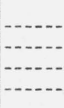 & $\mid--$ & 1. & - \\
\hline
\end{tabular}

Moisture samples representative of the respective panels were selected from unused material at the time of construction of the small panels. These also served as moisture samples for the corresponding flame-penetration specimens. For the fire-tube specimens the mois- 
ture samples were taken from the pieces cut off the ends of the sticks when cutting to length at the time of test. These were weighed immediately, dried at $105^{\circ} \mathrm{C}$ for $24 \mathrm{hr}$, and then reweighed. All specimens and samples were stored with the panels so as to be subjected to the same atmospheric conditions, and the material had been stored in buildings long enough to have reached moisture equilibrium. The principal descriptive data for the supplementary specimens are given in table 2.

\section{FIRE-TUBE TESTS}

The fire tube, developed by the Forest Products Laboratory, U. S. Department of Agriculture, consists of a sheet-metal tube about 50 in. long, which is suspended from one arm ot a balance beam (fig. 10). The lower end of the tube is enlarged and has screened sides and a solid bottom. Adjustable weights are placed on the other end of the beam to counterbalance the weight of the tube and specimen before test. A pointer attached to the center of the beam indicates the loss in weight on an adjustable scale during the test. Temperatures are measured at the top of the tube by means of a 14-gage chromelalumel thermocouple. A slot in the lower end of the tube permits the insertion of a low form of bunsen burner. The flame of this burner with its tall indistinct inner cone is adjusted to give a temperature of $180^{\circ} \mathrm{C}$ at the top of the tube.

In conducting a test, the beam weights and scale are adjusted so that the pointer indicates 0 -percent loss with the specimen in place and 100-percent loss when the tube is empty. After a preliminary heating of the tube, the specimen, $3 / 3$ by $3 / 4$ by 40 in., previously conditioned and weighed, is suspended centrally in the tube. The bunsen burner is then inserted about $1 \mathrm{in}$. below the lower end of the specimen and readings of temperature and loss in weight are taken at frequent intervals. The burner is removed at the end of $4 \mathrm{~min}$ and the readings are continued until 2 min after all flaming has ceased. Subsequently, the temperature and weight-loss data are plotted against time, from which derived results, such as the area under the time-temperature curve, are obtained.

TABLE 3.-Average results of fire-tube tests

\begin{tabular}{|c|c|c|c|c|c|c|c|c|c|c|}
\hline \multirow{3}{*}{$\begin{array}{l}\text { Specimens for } \\
\text { panel }\end{array}$} & \multirow{3}{*}{$\begin{array}{l}\text { Treat- } \\
\text { ment }\end{array}$} & \multicolumn{2}{|c|}{ Temperature } & \multirow{3}{*}{$\begin{array}{l}\text { Dura- } \\
\text { tion of } \\
\text { flam- } \\
\text { ing }{ }^{1}\end{array}$} & \multicolumn{3}{|c|}{ Total weight loss } & \multirow{2}{*}{\multicolumn{3}{|c|}{$\begin{array}{l}\text { Maximum rate } \\
\text { of weight loss }\end{array}$}} \\
\hline & & \multirow{2}{*}{$\operatorname{Max}$} & \multirow{2}{*}{$\begin{array}{c}\text { Area } \\
\text { under } \\
\text { tempera- } \\
\text { ture } \\
\text { curve }\end{array}$} & & \multicolumn{2}{|c|}{ Percentage } & \multirow{2}{*}{$\frac{\text { Actual }}{\text { Avg }}$} & & & \\
\hline & & & & & Range & Avg & & Min & $\operatorname{Max}$ & Avg \\
\hline $\begin{array}{l}2 \\
3 \\
4 \\
5\end{array}$ & $\begin{array}{r}\text { Percent } \\
8.2 \\
8.4 \\
8.0 \\
7.0 \\
8.4\end{array}$ & $\begin{array}{c}{ }^{\circ} \mathrm{C} \\
708 \\
387 \\
390 \\
460 \\
306\end{array}$ & $\begin{array}{r}\mathrm{C}-\min \\
1,055 \\
465 \\
335 \\
594 \\
292\end{array}$ & $\begin{array}{c}\min \\
4.3 \\
4.2 \\
4.4 \\
4.3 \\
4.3\end{array}$ & $\begin{array}{l}\text { Percent } \\
49 \text { to } 65 \\
27 \text { to } 67 \\
24 \text { to } 62 \\
28 \text { to } 69 \\
29 \text { to } 69\end{array}$ & \begin{tabular}{|r|} 
Percent \\
59 \\
44 \\
40 \\
49 \\
38
\end{tabular} & $\begin{array}{l}\mathrm{g} \\
68.6 \\
45.2 \\
42.7 \\
56.2 \\
42.8\end{array}$ & \begin{tabular}{|c|}
$\mathrm{g} / \mathrm{min}$ \\
24.7 \\
8.9 \\
9.0 \\
9.8 \\
9.9
\end{tabular} & $\begin{array}{c}\mathrm{g} / \mathrm{min} \\
28.5 \\
26.6 \\
20.3 \\
28.7 \\
20.7\end{array}$ & $\begin{array}{r}\mathrm{g} / \mathrm{min} \\
26.7 \\
16.1 \\
14.0 \\
19.4 \\
13.2\end{array}$ \\
\hline $\begin{array}{l}6 \\
7 \\
8 \\
9 \\
9 \\
10\end{array}$ & $\begin{array}{c}0 \\
0 \\
15.8 \\
16.0 \\
0\end{array}$ & $\begin{array}{l}724 \\
743 \\
183 \\
174 \\
731\end{array}$ & $\begin{array}{l}1,816 \\
1,630 \\
(2) \\
(2) \\
1,697\end{array}$ & $\begin{array}{l}5.1 \\
4.9 \\
4.0 \\
4.0 \\
4.9\end{array}$ & $\begin{array}{l}14 \text { to } 28 \\
14 \text { to } 23 \\
82 \text { to } 84\end{array}$ & $\begin{array}{l}83 \\
83 \\
19 \\
18 \\
83\end{array}$ & $\begin{array}{l}91.5 \\
91.4 \\
23.4 \\
22.8 \\
95.4\end{array}$ & \begin{tabular}{r|}
28.3 \\
31.0 \\
5.3 \\
5.4 \\
27.4
\end{tabular} & $\begin{array}{r}30.5 \\
32.9 \\
11.1 \\
9.7 \\
35.5\end{array}$ & $\begin{array}{r}29.4 \\
31.9 \\
7.5 \\
7.2 \\
31.8\end{array}$ \\
\hline 112 & $\begin{array}{c}16.2 \\
15.2 \\
0\end{array}$ & $\begin{array}{l}179 \\
180 \\
707\end{array}$ & $\begin{array}{l}(2) \\
(2) \\
1,888\end{array}$ & $\begin{array}{l}\text { 4. } 0 \\
\text { 4. } \\
5.5\end{array}$ & $\begin{array}{l}14 \text { to } 23 \\
13 \text { to } 28 \\
82 \text { to } 85\end{array}$ & $\begin{array}{l}19 \\
18 \\
84\end{array}$ & $\begin{array}{r}22.0 \\
21.8 \\
105.1\end{array}$ & $\begin{array}{r}4.7 \\
4.7 \\
29.7\end{array}$ & $\begin{array}{r}8.4 \\
10.6 \\
36.8\end{array}$ & $\begin{array}{r}7.0 \\
7.0 \\
32.6\end{array}$ \\
\hline $\begin{array}{l}C \\
D\end{array}$ & (n) & $\begin{array}{l}163 \\
192\end{array}$ & 13 & $\begin{array}{l}4.0 \\
4.0\end{array}$ & $\begin{array}{l}11 \text { to } 18 \\
21 \text { to } 33\end{array}$ & $\begin{array}{l}14 \\
26\end{array}$ & $\begin{array}{l}20.6 \\
30.4\end{array}$ & $\begin{array}{l}4.4 \\
7.9\end{array}$ & $\begin{array}{r}8.4 \\
15.5\end{array}$ & $\begin{array}{r}6.2 \\
10.6\end{array}$ \\
\hline
\end{tabular}


The results of the fire-tube tests are given in table 3. Average, minimum, and maximum values are given for the total weight loss in grams and the maximum rate of weight loss in grams per minute, while only averages are given for other figures although similar variations were also obtained in the latter results. The "maximum temperature" is the average of maximums recorded in individual tests and the area under the temperature curve, measured above the $180^{\circ}$ Cline, is given in "o C-min" units. The actual weight loss was calculated from the original weight of the specimen and the loss in weight (in percent) indicated by the pointer at the end of the test. The maximum rate of weight loss was calculated on the basis of the greatest loss in weight for a single minute occurring during the test.

Because of the nature of the specimen used, the concentration of treatment is the only factor studied in the fire-endurance tests which could possibly affect the results of the fire-tube tests. The relations between some of the results obtained in the fire-tube test, and the concentration of treatment for the specimens tested, are given in figure 11. The data for panel 1 have been omitted from figure 11 since they represented specimens from only a single board. The dashed portions of the curves have been drawn to correspond in general shape to that established by other tests $[1,3]$ since the present data are insufficient in the region of low concentration of salt. Similar relations hold between the concentration of treatment and other results obtained in the fire-tube tests, thus showing the distinct effect of treatment, particularly above 8 percent. The results are more consistent at higher concentrations, and it is significant that none of the specimens in the latter class continued flaming after burner removal.

\section{FLAME-PENETRATION TESTS}

In the flame-penetration test the specimen is supported in a horizontal position so that its center is 3 in. above the tip of a $\frac{3}{8}$-in. tirrill burner. For the specimens representative of panels 1 to 7 , inclusive, the rate of gas flow was adjusted so that the burner was producing about $2,800 \mathrm{Btu} / \mathrm{hr}$, and for the remaining tests this rate was increased to $3,000 \mathrm{Btu} / \mathrm{hr}$, but the difference is not considered significant as far as the results are concerned. Having adjusted the gas flow, the burner flame was adjusted by starting with a tall inner cone and increasing the air supply until the inner cone has just reached a minimum. With the gas used in this laboratory, a flame having an outer cone of about 7 in. and an inner cone of nearly 2 in. is obtained by the above procedure. A thermocouple is located at the center of the top surface of the specimen and temperature readings are taken at frequent intervals. Other data taken include time for light to come through any crack, time of flame penetration, time of ignition on the top surface, duration of flaming, and loss in weight. If ignition does not occur within $5 \mathrm{~min}$ after flame penetration, the burner is then removed.

The average results of these tests are given in table 4 . The rate of weight loss is found by dividing the total loss in weight by the sum of the time of burner application, plus the duration of flaming after burner removal. In order to place the weight-loss results on a comparable basis, the loss in weight in percent has been calculated for a specimen 10 in. square having the same loss in grams as the actual 
specimen. The resulting figure is termed the nominal loss and is thus corrected for departures in dimensions from the nominal size of $10 \mathrm{in}$. square.

The flame-penetration specimens were varied in the same respects as the panels, that is, in thickness, concentration of treatment, and
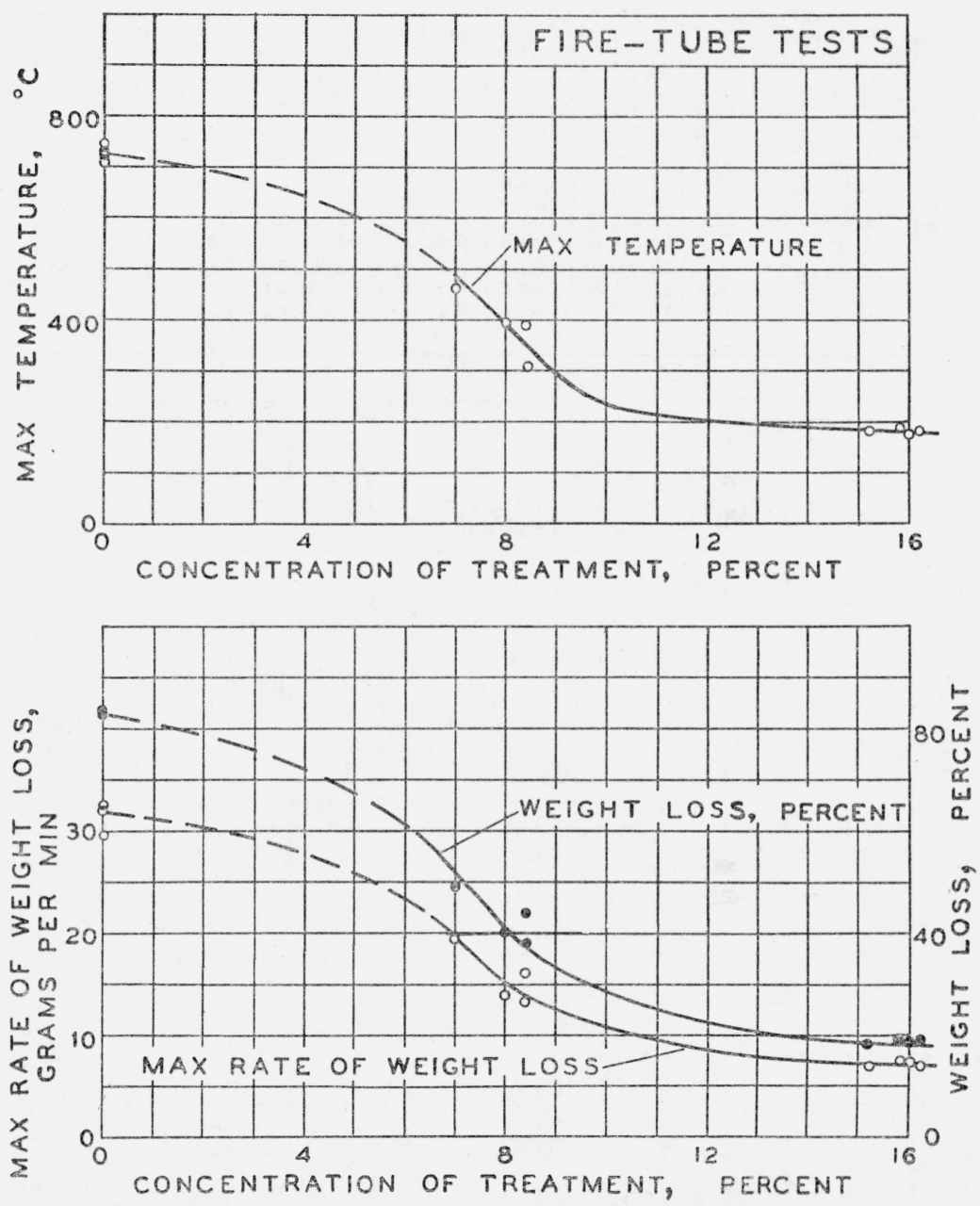

FIGURE 11.-Influence of concentration of treatment on maximum temperature, weight loss, and maximum rate of weight loss, in fire-tube tests. Data from tests of panel 1 have been omitted.

type of construction. Referring to figure 12, it is seen that all of the results based on time (upper half) and the loss in weight figures (lower half) increase rapidly as thickness of the specimen increases, for panels 1,2 , and 5 , which are comparable in amount of treatment and construction. Apparently, however, the rate of weight loss of these built-up specimens is affected very little, if at all, by thickness (see table 4). The time to flame penetration (see fig. 13), and other time data as well, do not appear to be greater for moderately treated 
TABLE 4.-Average results of flame-penetration tests

\begin{tabular}{|c|c|c|c|c|c|c|c|c|c|c|c|c|c|c|}
\hline \multirow{2}{*}{$\begin{array}{l}\text { Speci- } \\
\text { mens } \\
\text { for } \\
\text { panel }\end{array}$} & \multirow{2}{*}{$\begin{array}{c}\text { Thick- } \\
\text { ness }\end{array}$} & \multirow{2}{*}{$\begin{array}{l}\text { Treat- } \\
\text { ment }\end{array}$} & \multirow{2}{*}{$\begin{array}{c}\text { Time } \\
\text { of } \\
\text { light } \\
\text { through } \\
\text { speci- } \\
\text { men }\end{array}$} & \multicolumn{3}{|c|}{$\begin{array}{l}\text { Time of flame } \\
\text { penetration or } \\
\text { ignition }\end{array}$} & \multirow{2}{*}{$\begin{array}{l}\text { Du- } \\
\text { ra- } \\
\text { tion } \\
\text { of } \\
\text { flam- } \\
\text { ing }\end{array}$} & \multicolumn{2}{|c|}{$\begin{array}{l}\text { Time to } \\
\text { reach }\end{array}$} & \multicolumn{2}{|c|}{$\begin{array}{l}\text { Loss in } \\
\text { weight }\end{array}$} & \multicolumn{3}{|c|}{$\begin{array}{l}\text { Rate of weight } \\
\text { loss }\end{array}$} \\
\hline & & & & Min & Max & Avg & & ${ }_{\mathrm{C}}^{100^{\circ}}$ & $200^{\circ}$ & $\begin{array}{l}\text { Ac- } \\
\text { tual }\end{array}$ & $\begin{array}{l}\text { Nom- } \\
\text { inal }\end{array}$ & Min & Max & Avg \\
\hline & $\begin{array}{c}\text { in. } \\
3 / 4 \\
11 / 2 \\
21 / 4 \\
11 / 2 \\
21 / 4\end{array}$ & $\begin{array}{r}\text { Per- } \\
\text { cent } \\
8.2 \\
8.2 \\
8.2 \\
7.0 \\
8.5\end{array}$ & $\begin{array}{c}\min \\
12.7 \\
35.0 \\
95.6 \\
36.2 \\
92.2\end{array}$ & $\begin{array}{l}\min \\
16.2 \\
34.2 \\
95.5 \\
33.7 \\
92.7\end{array}$ & $\begin{array}{r}\min \\
18.0 \\
47.5 \\
142.7 \\
48.2 \\
115.3\end{array}$ & $\begin{array}{r}\min \\
17.2 \\
40.6 \\
113.7 \\
41.8 \\
101.2\end{array}$ & $\begin{array}{r}\min \\
0.3 \\
0.3 \\
12.5 \\
0.5 \\
5.1\end{array}$ & $\begin{array}{l}\min \\
11.0\end{array}$ & $\begin{array}{l}\min \\
15.1 \\
37.1 \\
98.5 \\
38.7 \\
86.1\end{array}$ & $\begin{array}{c}\mathrm{g} \\
86.0 \\
195.7 \\
469 \\
162.3 \\
371\end{array}$ & & $\begin{array}{l}\mathrm{g} / \\
\min \\
3.58 \\
3.40 \\
3.10 \\
3.12 \\
3.11\end{array}$ & $\underset{4.15}{\mathrm{~g} /}$ & $\begin{array}{c}\mathrm{g} / \\
\text { min } \\
3.83 \\
4.39 \\
3.52 \\
3.64 \\
3.38\end{array}$ \\
\hline & $\begin{array}{r}11 / 2 \\
3 / 4 \\
11 / 2 \\
11 / 2 \\
11 / 2\end{array}$ & $\begin{array}{c}0 \\
0 \\
15.8 \\
16.2 \\
0\end{array}$ & $\begin{array}{r}40.7 \\
8.0 \\
56.2 \\
56.4 \\
36.3\end{array}$ & $\begin{array}{r}29.0 \\
7.9 \\
50.5 \\
51.6 \\
34.5\end{array}$ & $\begin{array}{l}51.9 \\
10.0 \\
79.0 \\
75.4 \\
47.1\end{array}$ & $\begin{array}{r}42.8 \\
9.0 \\
62.3 \\
63.5 \\
38.9\end{array}$ & $\begin{array}{r}8.0 \\
10.5 \\
0.8 \\
1.2 \\
9.5\end{array}$ & $\begin{array}{r}33.8 \\
7.2 \\
43.8 \\
44.7 \\
27.5\end{array}$ & $\begin{array}{r}40.2 \\
8.7 \\
55.4 \\
57.6 \\
33.8\end{array}$ & $\begin{array}{l}293.3 \\
109.6 \\
195 \\
201 \\
341\end{array}$ & & & & $\begin{array}{l}2.92 \\
6.98\end{array}$ \\
\hline (n) & $\begin{array}{l}21 / 8 \\
21 / 8 \\
21 / 8\end{array}$ & $\begin{array}{c}17.0 \\
17.2 \\
0\end{array}$ & $\begin{array}{l}93.6 \\
90.4 \\
55.6\end{array}$ & $\begin{array}{l}95.6 \\
87.6 \\
50.4\end{array}$ & $\begin{array}{r}109.1 \\
99.3 \\
75.5\end{array}$ & $\begin{array}{r}100.6 \\
95.0 \\
60.6\end{array}$ & $\begin{array}{l}0.4 \\
0.7 \\
6.1\end{array}$ & $\begin{array}{l}77.2 \\
77.6 \\
48.4\end{array}$ & $\begin{array}{l}89.0 \\
86.9 \\
55.0\end{array}$ & $\begin{array}{l}310 \\
361 \\
422\end{array}$ & & $\begin{array}{l}2.88 \\
2.93 \\
5.02\end{array}$ & & $\begin{array}{l}2.92 \\
\text { 3. } 61 \\
6.48\end{array}$ \\
\hline
\end{tabular}

1 One specimen continued flaming in interior for $34.8 \mathrm{~min}$.
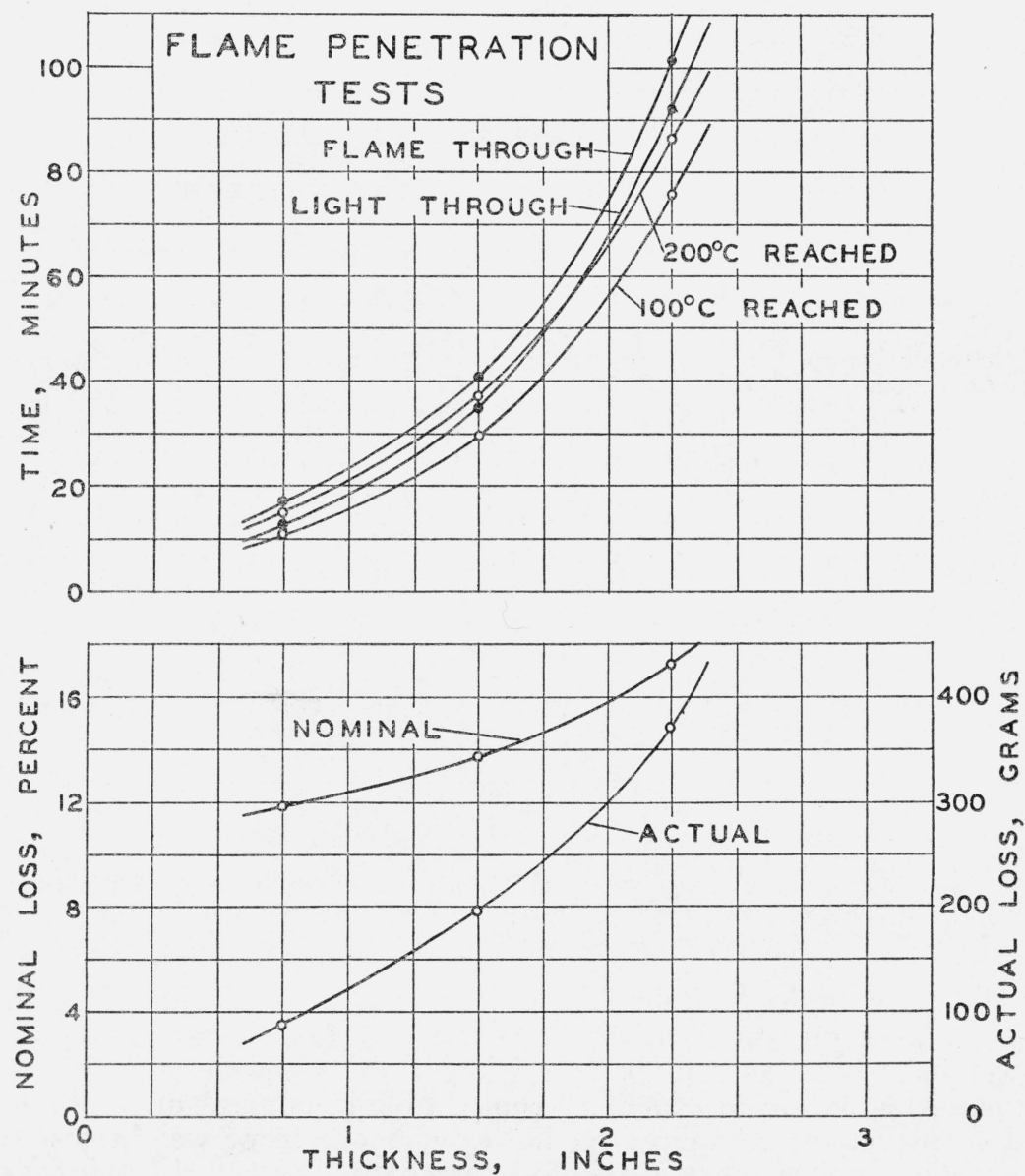

FiguRe 12.-Influence of thickness on time results and weight loss, in fiamepenetration tests.

Data from tests of panels 1,2 , and 5 . 
specimens than for untreated specimens, but are much greater for the well-treated specimens. On the other hand, the rate of weight loss decreased more rapidly with increasing amount of treatment in the range of low concentration than in the range of high concentration,
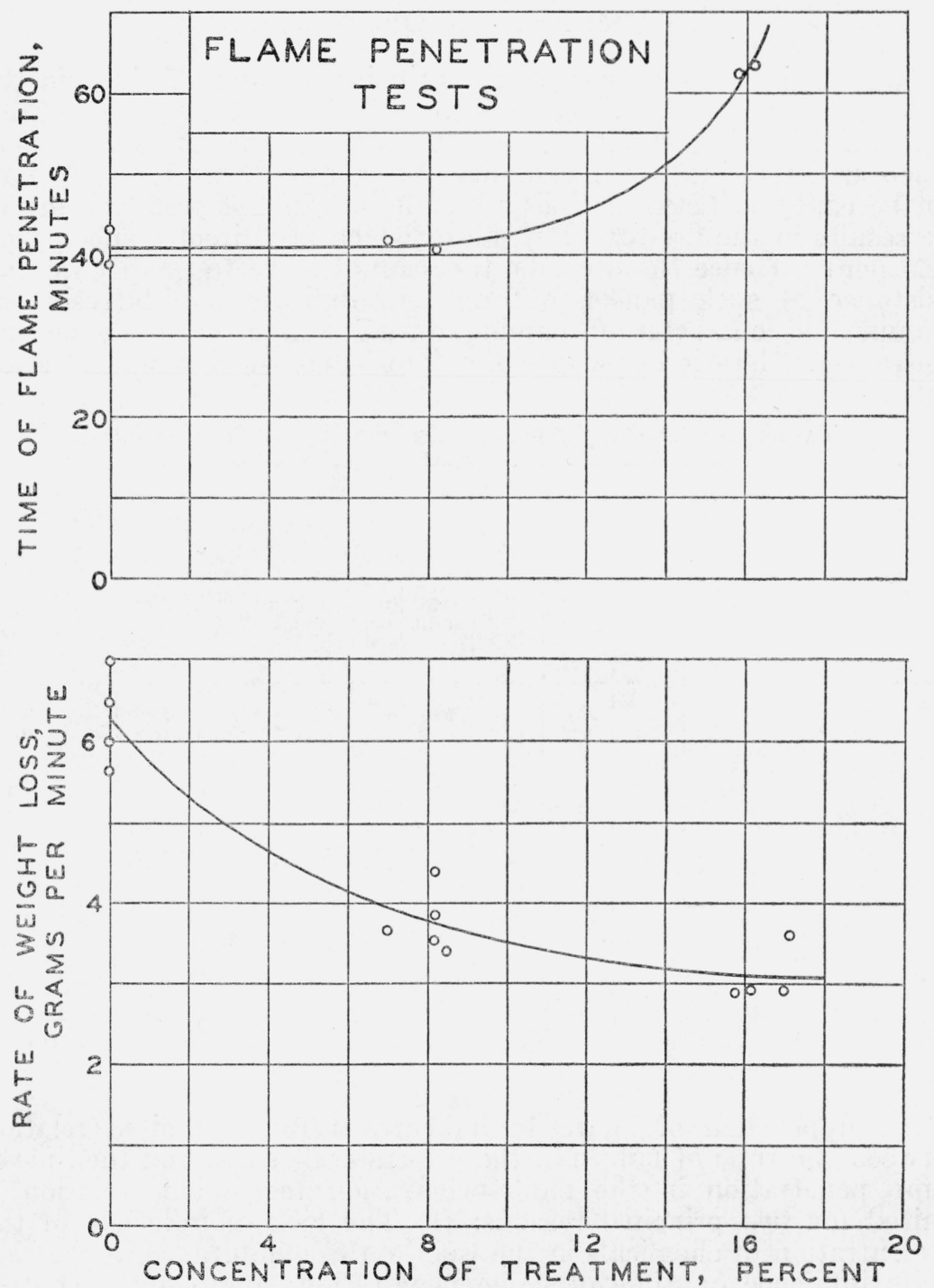

FIGURE 13.-Influence of concentration of treatment on time of flame penetration and rate of weight loss, in flame-penetration tests.

Data in upper half from tests of panels $2,4,6,8,9$, and 10. Data in lower half from tests of all panels.

as seen in the lower half of figure 13. Regarding the effect of type of construction, the specimens for panels 11 and 12 did not show the increased resistance to flame penetration over those for panels 3 and 5 , to be expected from the increased concentration of treatment and type of construction, although the average weight-loss results 
were lower. This might be attributable to the fact that there was always a joint in the core at the center of the specimens for panels 11 and 12 , and hence directly over the burner flame, while such was seldom the case for the $2 \frac{1}{4}$-in., three-ply specimens.

\section{COMPARISON OF RESULTS}

Table 5 gives a summary of the principal results obtained in the three types of tests. Since concentration of treatment does not appear to be an important factor in the fire resistance of treated-wood panels as determined by the standard fire-endurance test, no relations can be expected between the time of failure in this test and any of the results in the fire-tube test, all of which are directly affected by treatment. Hence the fire-tube test cannot serve to predict the fire resistance of such panels, but only to indicate qualitatively the amount and character of flaming during and after fire exposure. The same can be said of the rate of weight loss in the flame-penetration test.

TABLE 5.-Summary of principal results in three types of tests

\begin{tabular}{|c|c|c|c|c|c|c|c|c|c|c|c|}
\hline \multirow[b]{2}{*}{ Panel number } & \multicolumn{4}{|c|}{ Fire tests } & \multicolumn{4}{|c|}{ Fire-tube tests } & \multicolumn{3}{|c|}{$\begin{array}{l}\text { Flame-penetration } \\
\text { tests }\end{array}$} \\
\hline & Type & $\begin{array}{c}\text { Thick- } \\
\text { ness }\end{array}$ & $\begin{array}{l}\text { Treat- } \\
\text { ment }\end{array}$ & $\begin{array}{c}\text { Time } \\
\text { to fail- } \\
\text { ure }\end{array}$ & $\begin{array}{l}\text { Treat } \\
\text { ment }\end{array}$ & $\begin{array}{c}\text { Maxi- } \\
\text { mum } \\
\text { temp- } \\
\text { erature }\end{array}$ & $\begin{array}{l}\text { Loss in } \\
\text { weight }\end{array}$ & $\begin{array}{c}\text { Maxi- } \\
\text { mum } \\
\text { rate of } \\
\text { weight } \\
\text { loss }\end{array}$ & $\begin{array}{l}\text { Treat- } \\
\text { ment }\end{array}$ & $\begin{array}{c}\text { Flame } \\
\text { pene- } \\
\text { tration }\end{array}$ & $\begin{array}{l}\text { Aver- } \\
\text { age } \\
\text { rate of } \\
\text { weight } \\
\text { loss }\end{array}$ \\
\hline $\begin{array}{l}4 \\
5 \\
5\end{array}$ & $\begin{array}{l}\text { One ply } \\
\text { Two ply-.- } \\
\text { Three ply } 1 \\
\text { Two ply } \\
\text { Three ply.- }\end{array}$ & $\begin{array}{c}\text { in. } \\
3 / 4 \\
11 / 2 \\
21 / 4 \\
11 / 2 \\
21 / 4\end{array}$ & $\begin{array}{r}\text { Per- } \\
\text { cent } \\
8.2 \\
8.2 \\
8.3 \\
6.9 \\
8.6\end{array}$ & $\begin{array}{r}\min \\
9.4 \\
28.3 \\
40.5 \\
30.5 \\
45.3\end{array}$ & $\begin{array}{r}\text { Per- } \\
\text { cent } \\
8.2 \\
8.4 \\
8.0 \\
7.0 \\
8.4\end{array}$ & $\begin{array}{c}\circ \mathrm{C} \\
708 \\
387 \\
390 \\
460 \\
306\end{array}$ & $\begin{array}{c}\text { Per- } \\
\text { cent } \\
59 \\
44 \\
40 \\
49 \\
38\end{array}$ & \begin{tabular}{|r|}
$\mathrm{g} / \mathrm{min}$ \\
26.7 \\
16.1 \\
14.0 \\
19.4 \\
13.2
\end{tabular} & $\begin{array}{c}\text { Per- } \\
\text { cent } \\
8.2 \\
8.2 \\
8.2 \\
7.0 \\
8.5\end{array}$ & $\begin{array}{r}\min \\
17.2 \\
40.6 \\
113.7 \\
41.8 \\
101.2\end{array}$ & $\begin{array}{r}\mathrm{g} / \min \\
3.83 \\
4.39 \\
3.52 \\
3.64 \\
3.38\end{array}$ \\
\hline 9 & $\begin{array}{l}\text { Two ply... } \\
\text { One ply } \\
\text { Two ply.... } \\
\text { Two ply... } \\
\text { Two ply... }\end{array}$ & $\begin{array}{r}11 / 2 \\
3 / 4 \\
11 / 2 \\
11 / 2 \\
11 / 2\end{array}$ & $\begin{array}{c}0 \\
0 \\
15.9 \\
15.9 \\
0\end{array}$ & \begin{tabular}{r|}
29.4 \\
8.9 \\
31.5 \\
34.5 \\
32.3
\end{tabular} & $\begin{array}{c}0 \\
0 \\
15.8 \\
16.0 \\
0\end{array}$ & $\begin{array}{l}724 \\
743 \\
183 \\
174 \\
731\end{array}$ & $\begin{array}{l}83 \\
83 \\
19 \\
18 \\
83\end{array}$ & $\begin{array}{r}29.4 \\
31.9 \\
7.5 \\
7.2 \\
31.8\end{array}$ & $\begin{array}{c}0 \\
0 \\
15.8 \\
16.2 \\
0\end{array}$ & $\begin{array}{r}42.8 \\
9.0 \\
62.3 \\
63.5 \\
38.9\end{array}$ & $\begin{array}{l}5.98 \\
5.62 \\
2.90 \\
2.92 \\
6.98\end{array}$ \\
\hline 11 & $\begin{array}{l}\text { Core } \\
-\ldots \text { do }\end{array}$ & $\begin{array}{l}21 / 8 \\
21 / 8 \\
21 / 8\end{array}$ & $\begin{array}{c}17.0 \\
17.2 \\
0\end{array}$ & $\begin{array}{l}62.9 \\
72.1 \\
67.0\end{array}$ & $\begin{array}{c}16.2 \\
15.2 \\
0\end{array}$ & $\begin{array}{l}179 \\
180 \\
707\end{array}$ & $\begin{array}{l}19 \\
18 \\
84\end{array}$ & $\begin{array}{r}7.0 \\
7.0 \\
32.6\end{array}$ & $\begin{array}{l}17.0 \\
17.2 \\
0\end{array}$ & $\begin{array}{r}100.6 \\
95.0 \\
60.6\end{array}$ & $\begin{array}{l}2.92 \\
3.61 \\
6.48\end{array}$ \\
\hline
\end{tabular}

1 Center ply horizontal.

The upper half of figure 14 indicates a rather limited relation between the time of failure in the fire-endurance test and the time of flame penetration in the flame-penetration test. This relation is limited for two principal reasons: (1) The lack of influence of the concentration of chemicals in the wood on fire endurance in contrast to its influence on time of flame penetration; and (2) the contradictory influence of the type of construction on these two results. In comparing these two types of test, certain differences in the nature of the exposure should be noted. In the fire-endurance test, practically the entire surface of one side of a very large specimen is exposed to furnace temperatures. The fuel supplied to the furnace is constantly adjusted so that the furnace temperatures follow a definite curve. The exposure is severe, and any part of the structure having poor fire resistance can hardly escape the test and is most likely to be the 
place of failure. On the other hand, only a small portion of a small sample is subjected to the direct flame of a burner in the flamepenetration test. The fuel is supplied at a constant rate, but the exposure temperature is influenced by the combustibility of the

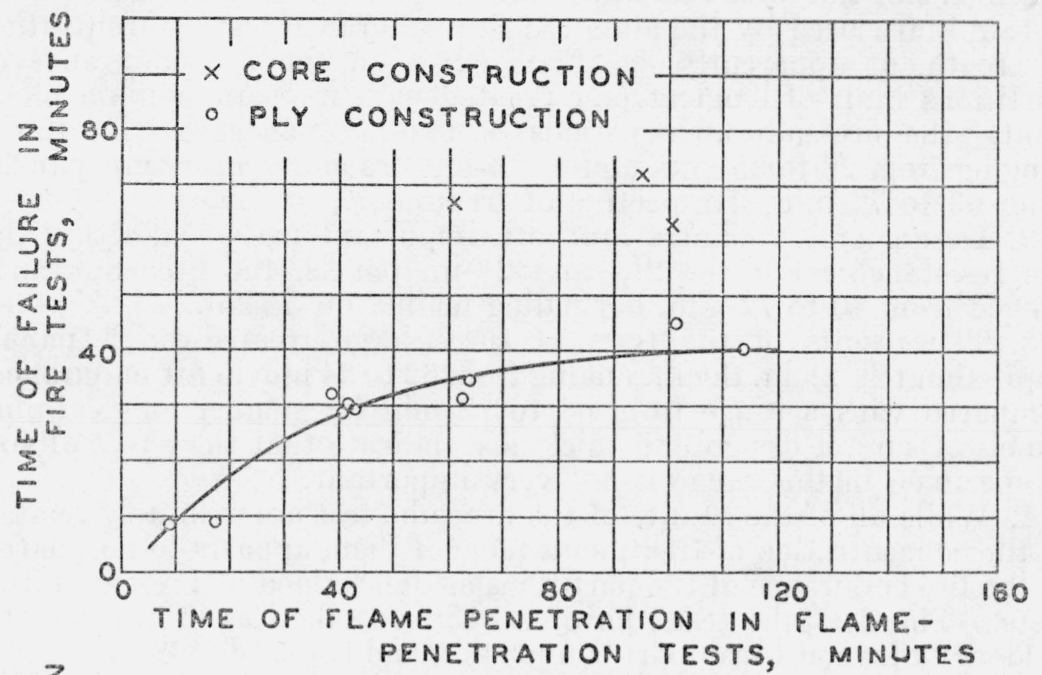

$\geq \frac{2}{2}$ PENETRATION TESTS, MINUTES

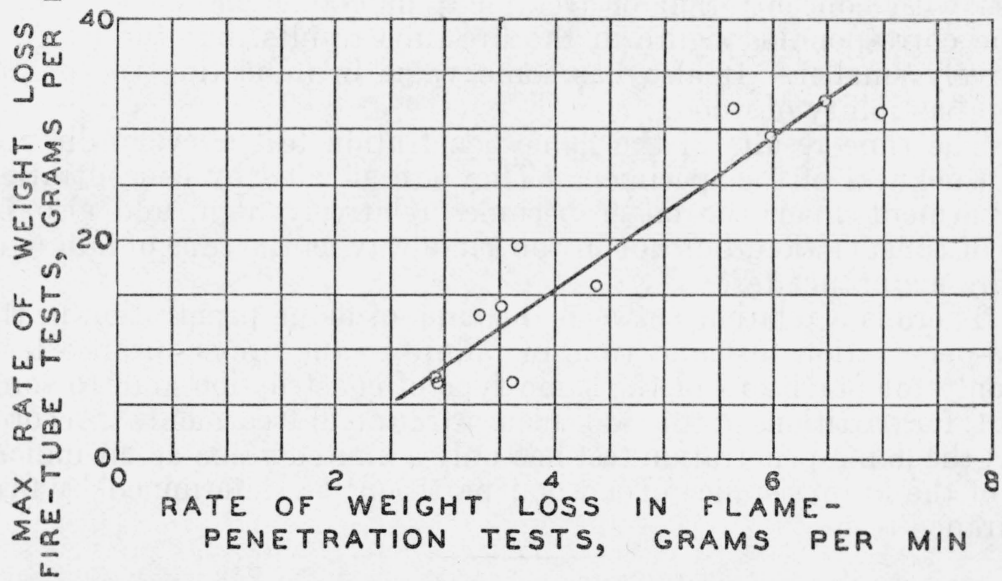

FIgURE 14.-Relations between (a) time of flame penetration in flame-penetration tests and time of failure in fire tests, and (b) rate of weight loss in flame-penetration tests and maximum rate of weight loss in fire-tube tests.

Data from tests of panel 1 omitted in lower half.

material being tested. The exposure is not as severe as in the fire test, and even with the use of several samples, the poorest parts of the structure, such as joints, may not be tested. These differences in the two tests may explain the differences in the results.

Finally, there is apparently a general relation between the maximum rate of weight loss obtained in the fire-tube test and the average rate of loss obtained in the flame-penetration test, as shown in the lower half of figure 14 . 


\section{SUMMARY AND CONCLUSIONS}

The principal conclusions to be drawn from the fire tests of partitions, the flame-penetration, and the fire-tube tests on representative specimens of the same materials are:

1. As measured by the standard fire-endurance test, concentration of treatment apparently has little effect on the fire endurance of partitions built of longleaf pine treated with monoammonium phosphate, the fire-endurance periods of two-ply panels, $1 \frac{1}{2}$ in. thick, ranging from 28 to $35 \mathrm{~min}$, and of $2 \frac{1}{8}$-in. core and veneer-type panels, from 63 to $72 \mathrm{~min}$, irrespective of treatment.

2. Design and thickness are both important factors affecting the fire resistance. For the 21/8- and 21/4-in. panels, the fire endurance ranged from 40 to $72 \mathrm{~min}$, depending mainly on design.

3. The results of the tests of three large treated birch panels approximately $2 \frac{1}{8} \mathrm{in}$. thick, ranging from 62 to $64 \mathrm{~min}$ in fire endurance, compared with a range from 63 to $72 \mathrm{~min}$ for smaller longleaf-pine panels of similar design and thickness, indicate that the effect of size of specimen in this range is not very important.

4. While all of the results of the fire-tube test are definitely related to the concentration of treatment, none of them appears to be related to the fire endurance of the partitions as determined in fire-endurance tests. The fire-tube tests, however, can be taken as indicating the tendency of wood to support combustion and spread fire [3].

5. The rate of weight loss obtained in the flame-penetration test varies with concentration of treatment in about the same manner as the corresponding figure in the fire-tube results, but the range is relatively smaller. It also has some value in indicating the degree of combustibility of wood.

6 . The time results in the flame-penetration test all vary directly with thickness of the specimen. They are affected by concentration of treatment when the latter becomes relatively high, and also by type of construction, but not in the same way as the time of failure in the fire-endurance test.

7. There is a relation between the time of flame penetration in the flame-penetration test and time of failure in the fire-endurance test, but only for partitions of the same type of construction and, to some extent, for partitions of the same concentration of treatment. Accordingly, the flame-penetration test has only a limited value as an indication of the fire resistance of a wood partition, as determined by fireendurance tests.

The author's acknowledgements are made to S. H. Ingberg for advice in the planning of the tests, and to N. D. Mitchell, F. M. Hoffheins, A. C. Hutton, and C. R. Beahm for aid in conducting the fire tests.

\section{REFERENCES}

[1] T. R. Truax and C. A. Harrison. Proc. Am. Soc. Testing Materials 29, pt. II, 973 (1929).

T. R. Truax and C. A. Harrison. Trans. Am. Soc. Mech. Engrs. 52:(No. 17) 33 (May-Aug. 1930).

G. M. Hunt, T. R. Truax, and C. A. Harrison. Proc. Am. Wood Preservers' Assn. 26, 130, 159 (1930).

T. R. Truax., Proc. Nat. Fire Protection Assn. 35, 189 (1931); Safety Eng. 62, 179 (1931). 
[2] E. F. Hartman, A. S. Williams, and R. C. Bastress. Proc. Am. Soc. Testing Materials 34, pt. II, 754 (1934).

[3] C. R. Brown. Proc. Am. Soc. Testing Materials 35, pt. II, 674 (1935).

[4] Standard specifications for fire tests of building construction and materials (C19-33), Am. Soc. Testing Materials Book of Standards, pt. II, 254 (1933). ASA Standard A-2-1934.

[5] Anonymous. Southern Lumberman 136 (No. 1762) 63 (Aug. 15, 1929). British Fire Prev. Comm. Red Books 193 and 194 (1914).

H. Riegelmann, et al. Report of Special Committee on Fireproof Wood (Multiple Dwelling Law Committee, New York, N. Y., 1930).

A. T. North. Arch. Forum 54, pt. 2, 247 (1931).

F. P. Cartwright, Southern Lumberman 142 (No. 1795) 39 (Jan. 15, 1931); Timberman 32 (No. 3), 116 (Jan. 1931); 32 (No. 4) 32 (Feb. 1931).

C. G. Schwalbe and K. Berling. Chem.-Ztg. 5\%, 881 (1933).

E. F. Hartman. N. Y. Lumber Trade J. Dec. 1, 1933, p. 14.

E. F. Hartman. Proc. Am. Wood-Preservers' Assn. 31, 218, 225 (1935).

[6] S. H. Ingberg and H. D. Foster. BS J. Research 2, 1 (1929) RP37.' (See page 33).

Washington, November 29, 1937. 